\title{
Catalytic racemization of secondary alcohols with new (arene)Ru(II)-NHC and (arene)Ru(II)-NHC-tertiary phosphine complexes
}

Natália Marozsán $^{\mathrm{a} *}$, Henrietta Horváth ${ }^{\mathrm{b}}$, Éva Kováts ${ }^{\mathrm{c}}$, Antal Udvardy ${ }^{\mathrm{a}}$, Anikó Erdei ${ }^{\mathrm{a}}$, Mihály

$$
\text { Purgel }^{\mathrm{a}}, \text { Ferenc Joó }^{\mathrm{a} *}
$$

${ }^{\mathrm{a} D e p a r t m e n t}$ of Physical Chemistry, University of Debrecen, Debrecen, P.O. Box 400, H-4002 Hungary

${ }^{\mathrm{b}}$ MTA-DE Redox and Homogeneous Catalytic Reaction Mechanisms Research Group,

Debrecen, P.O. Box 400, H-4002 Hungary

${ }^{\mathrm{c}}$ Institute for Solid State Physics and Optics, Wigner Research Centre for Physics, Hungarian Academy of Sciences, Konkoly Thege Miklós u. 29-33, H-1121 Budapest, Hungary

* Corresponding authors:

Natália Marozsán

Phone: +3652512900, ext. 22387

E-mail: marozsan.natalia@science.unideb.hu

Ferenc Joó

Phone: +3652512900, ext. 22382

E-mail: joo.ferenc@science.unideb.hu 


\begin{abstract}
Five new complexes of the type $\left[\mathrm{RuCl}_{2}(\mathrm{NHC})\left(\eta^{6}\right.\right.$-arene $\left.)\right](\mathbf{4}, \mathbf{5}$, and $\mathbf{6})$ and $\left[\mathrm{RuCl}(\mathrm{NHC})\left(\eta^{6}-\right.\right.$ arene $\left.)\left(\mathrm{PR}_{3}\right)\right] \mathrm{Cl}(\mathbf{7}$ and $\mathbf{8})(\mathrm{NHC}=N$-heterocyclic carbene=bmim, emim; arene=benzene, $p$ cymene; $\mathrm{PR}_{3}=\mathrm{PPh}_{3}$ or pta=1,3,5-triaza-7-phosphaadamantane) were synthetized and applied as catalysts (together with the known $\left[\mathrm{RuCl}_{2}(\mathrm{bmim})\left(\eta^{6}-p\right.\right.$-cymene) $)(3)$ with and without added $\mathrm{PPh}_{3}$ ) in racemization of optically active secondary alcohols in toluene. The highest catalytic activity, $\mathrm{TOF}=9.3 \mathrm{~h}^{-1}\left(e e\right.$ as low as $1.3 \%$ in $4 \mathrm{~h}$ at $\left.95^{\circ} \mathrm{C}\right)$ was observed in racemization of $(S)$-1-phenylethanol with a catalyst (4 mol\%) prepared in situ from 3 and 1 equivalent of $\mathrm{PPh}_{3}$. It is of practical significance that formation of acetophenone byproduct was suppressed to $3.5 \%$ by $17 \% v / v$ isopropanol in toluene. DFT calculations revealed that the rate determining step in the suggested reaction mechanism was the agostic coordination of hydrogen on the chiral carbon atom of the alcohol substrate.
\end{abstract}

Keywords: arene ligands; $N$-heterocyclic carbene complexes; racemization; ruthenium; phosphine 


\section{Introduction}

Complexes of transition metals with $N$-heterocyclic carbene ligands play outstanding role in homogeneous catalysis. First examples of such complexes were described by Öfele [1], and Wanzlik and Schönherr [2] already in 1968, and since then $N$-heterocyclic carbene complexes have been applied in almost all fields of chemistry and biochemistry [3-6]. Herrmann [7-11], Kühn [8-10], Nolan [3, 6, 12-16], Glorius [17, 18], and Perís [19, 20] -among others- have been instrumental in developing this area of homogeneous catalysis. Hydrogenation $[9,18$, 21], transfer hydrogenation [8, 22], redox isomerization [23], hydrodehalogenation [24, 25], hydroformylation $[7,11,26]$ and various $C$ - $C$ coupling reactions $[27,28]$ were frequent targets of investigations and could be carried out with high yields under mild conditions. One of the most prominent groups of $\mathrm{N}$-heterocyclic carbene (NHC) ligands is that of imidazol-2ylidenes, due to the relatively simple access to their catalytically active complexes with transition metal ions [3-6]. Water-soluble $\mathrm{Rh}(\mathrm{I})$-complexes with 1-methyl-3-(butyl-4sulfonate)imidazol-2-ylidene ligand were applied already in 1995 [11] as catalysts for hydroformylation of various olefins in aqueous biphasic systems, and catalytic reactions in aqueous solutions were intensively studied in later years, as well [21, 28-36].

Our work was focussed first on synthesis of water-soluble $\mathrm{Au}(\mathrm{I})$-based complexes carrying $\mathrm{N}$-sulfoalkyl- or $\mathrm{N}$-sulfoaryl-1,3-substituted-imidazol-2-ylidene ligands; these complexes proved excellent catalysts of alkyne hydration in partly or fully aqueous solutions [30, 34]. Another approach for achieving hydrosolubility was the synthesis of NHC-tertiary phosphine mixed ligand complexes such as $[\operatorname{Ir}(\operatorname{cod})(\mathrm{emim})(m \mathrm{tppms})]$ with a water-soluble tertiary phosphine ligand (mono- or trisulfonated triphenylphosphine, $m$ tppms or $m$ tppts, respectively, or 1,3,5-triaza-7-phosphadamantane, pta) [35]. Such complexes showed high activity in hydrodehalogenation of organic halides [25], in hydrogenation of alkenes [35] and in redox isomerization of allylic alcohols $[23,35]$. [ $\operatorname{Ir}(\operatorname{cod})(\operatorname{emim})(m \mathrm{tppms})]$ showed the 
highest known catalytic activity in decomposition of aqueous formate salts to $\mathrm{H}_{2}$ and $\mathrm{HCO}_{3}{ }^{-}$ and in hydrogenation of bicarbonate to formate; this reversible reaction could be applied for construction of a hydrogen battery [36]. Ru(II)-NHC complexes can be readily obtained in reaction of $\left[\left\{\mathrm{RuX}_{2}\left(\eta^{6} \text {-arene }\right)\right\}_{2}\right]$ precursors $\left(\mathrm{X}^{-}=\right.$halide, arene $=$benzene or $p$-cymene $)$ with suitable carbene sources such as for example the easily accessible $[\mathrm{Ag}(\mathrm{NHC})] \mathrm{X}$ complexes $[21,25,37]$.

Racemization of optically active secondary alcohols is an important step in dynamic kinetic resolutions [38-41]. The reaction can be regarded as a catalytic intramolecular dehydrogenation/ hydrogenation process as shown by the example of the reaction of $(S)-1$ phenylethanol (Scheme 1), and indeed, in many cases the corresponding ketone is obtained as byproduct.

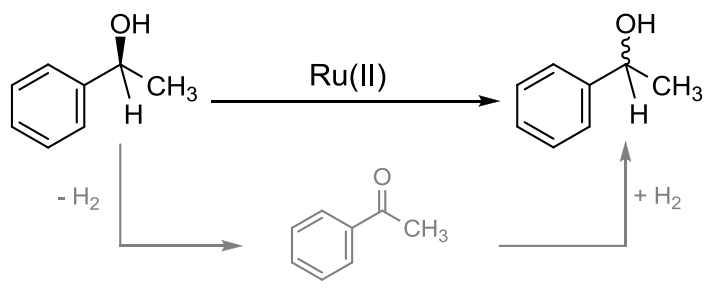

Scheme1. Racemization of (S)-1-phenylethanol

Since the groundbreaking discovery of Shvo's catalyst [42-43] several $\mathrm{Ru}(\mathrm{II}), \mathrm{Rh}(\mathrm{I})$ and $\operatorname{Ir}(\mathrm{I})$ complexes were found capable for racemization of secondary alcohols under relatively mild conditions [12-15, 44-57], although ruthenium catalysts are the most abundant. The reaction may proceed with formation of $\mathrm{M}-\mathrm{H}$ monohydride intermediates $(\mathrm{Rh}, \mathrm{Ir})$ or with $\mathrm{M}(\mathrm{H})_{2}$ dihydride species $(\mathrm{Ru})[55]$.

Park and co-workers studied the catalytic effect of $\left[\mathrm{RuCl}\left(\eta^{5}\right.\right.$-indenyl $\left.)\left(\mathrm{PPh}_{3}\right)_{2}\right]$ in racemization of secondary alcohols [44]. It was found that with $1 \mathrm{~mol} \%$ of this catalyst racemization of $(S)$-1-phenylethanol in $\mathrm{CH}_{2} \mathrm{Cl}_{2}$ was complete in 20 min $\left(\mathrm{TOF}=150 \mathrm{~h}^{-1}\right.$; $\mathrm{TOF}=$ turnover frequency $=(\mathrm{mol}$ reacted substrate $\left.) \times(\text { mol catalyst } \times \text { time })^{-1}\right)$ at $25^{\circ} \mathrm{C}$ in presence of $\mathrm{KOH}$ as base. They have also established [41] that $\left[\left\{\mathrm{RuCl}_{2}\left(\eta^{6}-p \text {-cymene }\right)\right\}_{2}\right]$, catalyzed 
efficiently the racemization of allylic alcohols at $40^{\circ} \mathrm{C}$ in $\mathrm{CH}_{2} \mathrm{Cl}_{2}$ in the presence of triethylamine. For example, with 4 mol\% of this catalyst $(S)$-1-phenylbuten-3-ol afforded the racemic mixture in $5 \mathrm{~h}\left(\mathrm{TOF}=5.5 \mathrm{~h}^{-1}\right.$ at full conversion); racemization was accompanied by modest dehydrogenation (25\% yield of the corresponding ketones) [45].

Csjernyik, Bogár and Bäckvall investigated the racemization of secondary alcohols with various $\left[\mathrm{RuXL}_{2}\left(\eta^{5}-\mathrm{C}_{5}(\mathrm{R})_{5}\right] \quad\left(\mathrm{X}=\mathrm{Cl}^{-}, \mathrm{Br}^{-} ; \mathrm{L}=\mathrm{CO}\right.\right.$ or $\left.\mathrm{PPh}_{3} ; \mathrm{R}=\mathrm{H}, \mathrm{CH}_{3}, \mathrm{Ph}\right)$ catalysts in toluene in the presence of small amounts of 2-propanol [46]. The reactions proceeded at room temperature with exceedingly high reaction rates. For example, $\left[\mathrm{RuCl}(\mathrm{CO})_{2}\left(\eta^{5}-\mathrm{C}_{5}(\mathrm{Ph})_{5}\right]\right.$ catalyzed the racemization of $(S)$-1-phenylethanol with a TOF $=2000 \mathrm{~h}^{-1}$ (at $\mathrm{t}_{1 / 2}$ of the reaction). Hydrido complexes of the type $\left[\mathrm{RuHL}_{2}\left(\eta^{5}-\mathrm{C}_{5}(\mathrm{R})_{5}\right]\right.$ (formed on action of 2-propanol and the applied base) were identified as active intermediates and on this basis a reaction mechanism was also suggested.

Ikariya and co-workers synthetized catalysts for racemization of various secondary alcohols in reaction of $\left[\mathrm{RuCl}\left(\eta^{5}-\mathrm{Cp}^{*}\right)(\mathrm{COD})\right]\left(\mathrm{Cp}^{*}=\right.$ pentamethylcyclopentadienyl $)$ and bidentate diphenylphosphinoalkylamine, $\mathrm{Ph}_{2}-\mathrm{CH}_{2} \mathrm{CH}_{2}-\mathrm{NR}^{1} \mathrm{R}^{2}$ ligands [47]. In racemization of (R)-1-phenylethanol $\left(30^{\circ} \mathrm{C}\right.$, toluene $)$, most of these catalysts were characterized by $\mathrm{TOF} \leq 40$ $\mathrm{h}^{-1}$; however, with $\mathrm{R}^{1}=\mathrm{R}^{2}=\mathrm{H}$ the TOF reached $479 \mathrm{~h}^{-1}$, while in case of $\mathrm{R}_{1}=\mathrm{H}, \mathrm{R}_{2}=\mathrm{CH}_{3}$ the turnover frequency was $191 \mathrm{~h}^{-1}$. Amido complexes of the type $\left[\mathrm{Ru}\left(\eta^{5}-\mathrm{Cp}^{*}\right)\left(\mathrm{HN}-\mathrm{CH}_{2} \mathrm{CH}_{2^{-}}\right.\right.$ $\left.\mathrm{PPh}_{2}\right)$ ] were suggested as active catalytic species in these reactions.

The well-defined 16-electron $\left[\mathrm{RuCl}\left(\mathrm{Cp}^{*}\right)(\mathrm{NHC})\right]$ complexes were shown highly active in racemizations by Bosson and Nolan [12,13]; for example with 2 mol\% of the catalyst with NHC=1,3-bis-cyclohexyl-2-imidazolylidene (ICy), (S)-1-phenylethanol was converted to a racemic mixture in $30 \mathrm{~min}$ (room temperature, toluene) corresponding to TOF=200 $\mathrm{h}^{-1}$. The catalytic activity showed a large NHC ligand dependence, exemplified by $\left[\mathrm{RuCl}\left(\mathrm{Cp}^{*}\right)(\mathrm{IMes})\right]$ yielding only $13 \%$ racemization under the same conditions. The analogous hydroxide 
complexes $\left[\mathrm{Ru}(\mathrm{OH})\left(\mathrm{Cp}^{*}\right)(\mathrm{NHC})\right]$ were much less effective $(5 \mathrm{~mol} \% \mathrm{Ru}$, full racemizations at $50^{\circ} \mathrm{C}$, overnight), however, their intrinsic basicity allowed the exclusion of an external base (e.g. $\mathrm{KO}^{t} \mathrm{Bu}$ ) [14]. The mechanism of racemization of secondary alcohols with these 16electron $\mathrm{Ru}(\mathrm{II})$-catalysts were extensively studied both experimentally and by theoretical calculations [13]. High racemization activity requires a free coordination site on ruthenium which is available in the 16-electron $\mathrm{Ru}(0)$-complexes, or in the 18 -electron ones with an easily dissociable ligand; this requirement was also confirmed in the experimental and theoretical studies of Cao et al [58].

Based on the evaluation of literature results we reasoned that synthesis of new $\mathrm{Ru}(\mathrm{II})-$ NHC and Ru(II)-NHC-phosphine complexes could lead to active catalysts for racemization. It was observed earlier that in aqueous solution $\left[\mathrm{RuCl}_{2}(\mathrm{bmim})\left(\eta^{6}-p\right.\right.$-cymene $\left.)\right]$ could easily undergo replacement of chloride by $\mathrm{H}_{2} \mathrm{O}$ or by a water-soluble tertiary phosphine ligand (pta or $m$ tppms) [21]. This finding opened the way to synthesis of several new complexes with the general composition of $\left[\mathrm{RuCl}_{2}(\mathrm{NHC})\left(\eta^{6}\right.\right.$-arene $\left.)\right] \quad(\mathrm{NHC}=\mathrm{bmim} \quad$ or emim=1-ethyl-3methylimidazole-2-ylidene; arene=benzene or $p$-cymene $)$ as well as of $\left[\operatorname{RuCl}(\mathrm{emim})\left(\eta^{6}-p\right.\right.$ cymene $\left.)\left(\mathrm{PR}_{3}\right)\right] \mathrm{Cl}\left(\mathrm{PR}_{3}=\mathrm{pta}\right.$ or $\left.\mathrm{PPh}_{3}\right)$. Here we report the synthesis and characterization of such complexes together with their catalytic properties in racemization of optically active secondary alcohols.

\section{Experimental}

$\left[\left\{\mathrm{RuCl}_{2}\left(\eta^{6}-p \text {-cymene }\right)\right\}_{2}\right] \quad$ (1) $[59], \quad\left[\left\{\mathrm{RuCl}_{2}\left(\eta^{6}-\mathrm{C}_{6} \mathrm{H}_{6}\right)\right\}_{2}\right] \quad$ (2) $\quad[60], \quad\left[\mathrm{RuCl}_{2}(\mathrm{bmim})\left(\eta^{6}-p-\right.\right.$ cymene)] (3) [21], $\left[\mathrm{RuCl}_{2}\left(\eta^{6}-p\right.\right.$-cymene)(pta)] [61, 62] and pta [63] were prepared according to literature methods. All other materials were commercial reagents and were used as received. 
Technical details for characterization of the new complexes 4-8 (NMR, ESI-MS, X-ray crystallography) together with those of theoretical calculations are given in the Supporting Information.

\subsection{Synthesis of complexes 4-8}

$\left[\mathrm{RuCl}_{2}(\mathrm{emim})\left(\eta^{6}-p\right.\right.$-cymene $\left.)\right](\mathbf{4}),\left[\mathrm{RuCl}_{2}(\mathrm{bmim})\left(\eta^{6}-\mathrm{C}_{6} \mathrm{H}_{6}\right)\right](\mathbf{5})$, and $\left[\mathrm{RuCl}_{2}(\mathrm{emim})\left(\eta^{6}-\mathrm{C}_{6} \mathrm{H}_{6}\right)\right]$ (6) were synthetized from the respective $\left[\left\{\mathrm{RuCl}_{2}\left(\eta^{6} \text {-arene }\right)\right\}_{2}\right]$ dimer and $\mathrm{NHC} . \mathrm{HCl}$ by the silver-carbene transfer method [21, 37]. 7 and $\mathbf{8}$ were obtained by addition of $\mathrm{PPh}_{3}$ or pta, respectively, to 4 . Syntheses and characterization data of $\mathbf{4}$ and $\mathbf{7}$ are given below as representative examples, for detailed procedures and characterization of 4-8 see SI.

\section{$\left[\operatorname{RuCl}_{2}(\mathbf{e m i m})\left(\eta^{6}-p\right.\right.$-cymene) $(4)$ (Procedure S1.1)}

$252 \mathrm{mg}(1.72 \mathrm{mmol})$ emim. $\mathrm{HCl}$ was dissolved in $25 \mathrm{~mL} \mathrm{CH}_{2} \mathrm{Cl}_{2}$ in a Schlenk tube. To this solution was added $240 \mathrm{mg}(1.03 \mathrm{mmol}) \mathrm{Ag}_{2} \mathrm{O}$ under an argon atmosphere. The mixture was refluxed for $3 \mathrm{~h}$, let to cool to room temperature and was filtered through Hyflo ${ }^{\circledR}$ Super-Cel ${ }^{\circledR}$ filter aid. The resulting solution of $\left[\mathrm{Ag}(\mathrm{emim})_{2}\right]\left[\mathrm{AgCl}_{2}\right]$ was added under $\mathrm{Ar}$ to a solution of $527 \mathrm{mg}(0.86 \mathrm{mmol})\left[\left\{\mathrm{RuCl}_{2}\left(\eta^{6}-p \text {-cymene }\right)\right\}_{2}\right]$ in $5 \mathrm{~mL} \mathrm{CH}_{2} \mathrm{Cl}_{2}$ which resulted in immediate formation of a white precipitate. The reaction mixture was stirred for $2 \mathrm{~h}$ at $40^{\circ} \mathrm{C}$, finally $\mathrm{AgCl}$ was removed by filtration. The red filtrate was concentrated by evaporation of the solvent yielding a dark reddish brown sticky residue which was kept overnight in the freezer compartment of a refrigerator. Afterwards the solid was triturated several times with small portions of cold diethyl ether until it solidified giving $\mathbf{4}$ as orange yellow powder. Dried under argon. Yield: $470 \mathrm{mg}(66 \%)$. The product can be recrystallized from $\mathrm{CH}_{2} \mathrm{Cl}_{2}$ by layering hexane on top of the solution; crystals for single crystal X-ray diffraction measurements were also obtained using this procedure. 
Elemental analysis (\%). Found: C, 45.98; H, 5.67; N, 6.69\%; Calculated for $\mathrm{C}_{16} \mathrm{H}_{24} \mathrm{~N}_{2} \mathrm{Cl}_{2} \mathrm{Ru}$ : C, 46.15; H, 5.81; N, $6.72 \%$.

ESI-MS $\left(\mathrm{CH}_{3} \mathrm{OH}\right): \mathrm{m} / \mathrm{z} 381.065\left([\mathrm{M}-\mathrm{Cl}]^{+}\right.$, calc. 381.067); correct isotope distribution pattern (Figure S5).

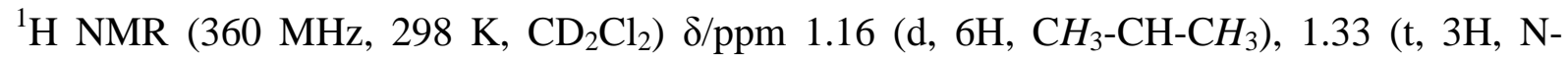
$\mathrm{CH}_{2} \mathrm{CH}_{3}$ ), 1.89 (s, 3H, C-CH $\mathrm{CH}_{3}, 2.84$ (heptet, $1 \mathrm{H}, \mathrm{CH}_{3}-\mathrm{CH}-\mathrm{CH}_{3}$ ), 3.87 (s, 3H, N-CH ( $_{3}, 4.17$ (quartet, 2H, N-CH $\left.\mathrm{CH}_{3}\right), 4.96(\mathrm{~d}, 2 \mathrm{H},-\mathrm{CH}-), 5.30$ (d, 2H, $\left.-\mathrm{CH}-\right), 7.00(\mathrm{~d}, 1 \mathrm{H}, \mathrm{N}-\mathrm{CH}=\mathrm{CH}-\mathrm{N})$, $7.07(\mathrm{~d}, 1 \mathrm{H}, \mathrm{N}-\mathrm{CH}=\mathrm{CH}-\mathrm{N})$ (Figure S3).

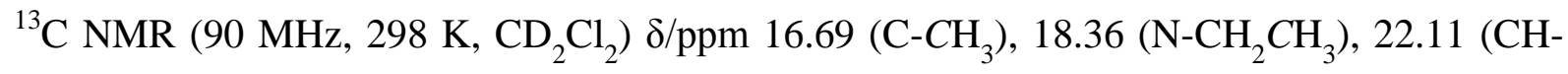
$\left.\mathrm{CH}_{3}\right), 30.74\left(\mathrm{CH}-\mathrm{CH}_{3}\right), 39.31\left(\mathrm{~N}-\mathrm{CH}_{3}\right), 46.23\left(\mathrm{~N}-\mathrm{CH}_{2}\right), 81.79,85.80(\mathrm{CH}-\mathrm{CH}), 98.85(\mathrm{C}-$ $\left.\mathrm{CH}_{3}\right), 109.19\left(\mathrm{CH}-\mathrm{CH}\left(\mathrm{CH}_{3}\right)_{2}\right), 121.18,124.20(\mathrm{~N}-\mathrm{CH}=\mathrm{CH}-\mathrm{N}), 173.80(\mathrm{NCN})$ (Figure S4).

\section{Synthesis of $\left[\mathbf{R u C l}_{\mathbf{2}}(\mathbf{b m i m})\left(\boldsymbol{\eta}^{6}-\mathbf{C}_{\mathbf{6}} \mathbf{H}_{\mathbf{6}}\right)\right](\mathbf{5})$ (Procedure S1.2)}

Complex 5 was prepared according to the procedure given above for $\mathbf{4}$ with the following amounts of reagents: $300 \mathrm{mg}(1.72 \mathrm{mmol})$ bmim. $\mathrm{HCl}, 240 \mathrm{mg}(1.03 \mathrm{mmol}) \mathrm{Ag}_{2} \mathrm{O}, 430 \mathrm{mg}$ $(0.86 \mathrm{mmol})\left[\left\{\mathrm{RuCl}_{2}\left(\eta^{6}-\mathrm{C}_{6} \mathrm{H}_{6}\right)\right\}_{2}\right]$. Orange yellow powder. Yield $400 \mathrm{mg}(60 \%)$. The product can be recrystallized from $\mathrm{CH}_{2} \mathrm{Cl}_{2}$ by layering hexane on top of the solution; crystals for single crystal X-ray diffraction measurements were also obtained using this procedure.

Elemental analysis (\%): Found: C, 43.19; H, 5.27; N, 7.06; Calculated for $\mathrm{C}_{14} \mathrm{H}_{20} \mathrm{~N}_{2} \mathrm{Cl}_{2} \mathrm{Ru}$ : C, 43.30; H, 5.19; N, 7.21.

ESI-MS $\left(\mathrm{CH}_{3} \mathrm{OH}\right): \mathrm{m} / \mathrm{z} 353.036\left([\mathrm{M}-\mathrm{Cl}]^{+}\right.$, calc. 353.035); $317.056\left([\mathrm{M}-2 \mathrm{Cl}-\mathrm{H}]^{+}\right.$, calc. 317.059); 335.068 ([M-2Cl+OH $]^{+}$, calc. 335.070); correct isotope distribution patterns (Figure S10).

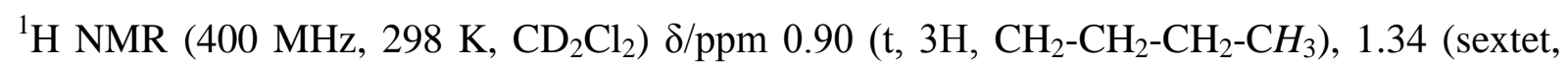
2H, $\mathrm{CH}_{2}-\mathrm{CH}_{2}-\mathrm{CH}_{2}-\mathrm{CH}_{3}$ ), 1.70 (quintet, $2 \mathrm{H}, \mathrm{CH}_{2}-\mathrm{CH}_{2}-\mathrm{CH}_{2}-\mathrm{CH}_{3}$ ), 3.86 (s, 3H, N-CH $\mathrm{CH}_{3}$ ), 4.21 (t, 
$\left.2 \mathrm{H}, \mathrm{CH}_{2}-\mathrm{CH}_{2}-\mathrm{CH}_{2}-\mathrm{CH}_{3}\right), 5.44\left(\mathrm{~s}, 6 \mathrm{H}, \mathrm{C}_{6} \mathrm{H}_{6}\right) 6.98(\mathrm{~d}, 1 \mathrm{H}, \mathrm{N}-\mathrm{CH}=\mathrm{CH}-\mathrm{N}) 7.02(\mathrm{~d}, 1 \mathrm{H}, \mathrm{N}-$ $\mathrm{CH}=\mathrm{CH}-\mathrm{N}$ ) (Figure S8).

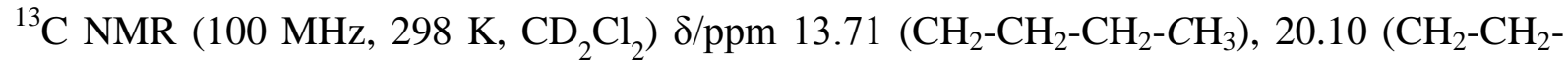
$\left.\mathrm{CH}_{2}-\mathrm{CH}_{3}\right), 33.80\left(\mathrm{CH}_{2}-\mathrm{CH}_{2}-\mathrm{CH}_{2}-\mathrm{CH}_{3}\right), 39.28\left(\mathrm{~N}-\mathrm{CH}_{3}\right), 51.15\left(\mathrm{~N}-\mathrm{CH}_{2}\right), 86.17(\mathrm{CH}-\mathrm{CH})$, 121.57, $124.14(\mathrm{~N}-\mathrm{CH}=\mathrm{CH}-\mathrm{N}), 171.21(\mathrm{NCN})$ (Figure $\mathrm{S} 9)$.

Synthesis of $\left[\mathbf{R u C l}_{2}(\mathbf{e m i m})\left(\eta^{6}-\mathbf{C}_{6} \mathbf{H}_{6}\right)\right](6)$ (Procedure S1.3)

Complex 6 was prepared according to the procedure given above for $\mathbf{4}$ with the following amounts of reagents: $252 \mathrm{mg}(1.72 \mathrm{mmol})$ emim. $\mathrm{HCl}, 240 \mathrm{mg}(1.03 \mathrm{mmol}) \mathrm{Ag}_{2} \mathrm{O}, 430 \mathrm{mg}$ (0.86 mmol) $\left[\left\{\mathrm{RuCl}_{2}\left(\eta^{6}-\mathrm{C}_{6} \mathrm{H}_{6}\right)\right\}_{2}\right]$. Orange yellow powder. Yield $280 \mathrm{mg}(45 \%)$.

Elemental analysis (\%): Found: C, 40.47; H, 4.59; N, 7.30; Calculated for $\mathrm{C}_{12} \mathrm{H}_{16} \mathrm{~N}_{2} \mathrm{Cl}_{2} \mathrm{Ru}$ : C, 40.00; H, 4.48; N, 7.78.

ESI-MS $\left(\mathrm{CH}_{3} \mathrm{OH}\right): \mathrm{m} / \mathrm{z} 325.005\left([\mathrm{M}-\mathrm{Cl}]^{+}\right.$, calc. 325.004); $289.024\left([\mathrm{M}-2 \mathrm{Cl}-\mathrm{H}]^{+}\right.$, calc. 289.028); 307.037 ([M-2Cl+OH $]^{+}$, calc. 307.038); correct isotope distribution patterns (Figure S15).

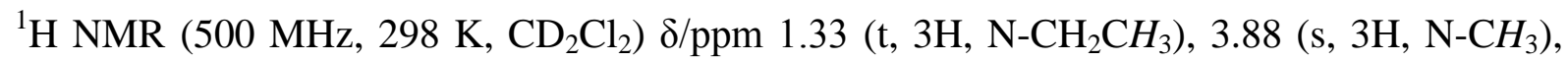
4.17 (quartet, 2H, N-CH $\left.\mathrm{CH}_{3}\right), 5.44\left(\mathrm{~s}, 6 \mathrm{H}, \mathrm{C}_{6} \mathrm{H}_{6}\right), 6.98(\mathrm{~d}, 1 \mathrm{H}, \mathrm{N}-\mathrm{CH}=\mathrm{CH}-\mathrm{N}), 7.02(\mathrm{~d}, 1 \mathrm{H}$, $\mathrm{N}-\mathrm{CH}=\mathrm{CH}-\mathrm{N})$ (Figure $\mathrm{S} 13)$.

${ }^{13} \mathrm{C}$ NMR $\left(125 \mathrm{MHz}, 298 \mathrm{~K}, \mathrm{CD}_{2} \mathrm{Cl}_{2}\right) \delta / p p m 16.75\left(\mathrm{~N}^{-\mathrm{CH}_{2}} \mathrm{CH}_{3}\right), 39.26\left(\mathrm{~N}_{-} \mathrm{CH}_{2} \mathrm{CH}_{3}\right), 46.19$ $\left(\mathrm{N}-\mathrm{CH}_{3}\right), 86.16(\mathrm{CH}-\mathrm{CH}), 121.22,124.22(\mathrm{~N}-\mathrm{CH}=\mathrm{CH}-\mathrm{N}), 171.35(\mathrm{NCN})$ (Figure S14).

\section{Synthesis of $\left[\mathbf{R u C l}(\mathbf{e m i m})\left(\eta^{6}-p\right.\right.$-cymene $\left.)\left(\mathbf{P P h}_{3}\right)\right] \mathrm{Cl}(\mathbf{7})$ (Procedure S1.4)}

Under argon, $30 \mathrm{mg}\left(7.20 \times 10^{-2} \mathrm{mmol}\right)\left[\mathrm{RuCl}_{2}(\mathrm{emim})\left(\eta^{6}-p\right.\right.$-cymene $\left.)\right](4)$ was dissolved in 5 $\mathrm{mL}$ dry methanol. To the resulting orange yellow solution $18.9 \mathrm{mg}\left(7.20 \times 10^{-2} \mathrm{mmol}\right)$ powdered $\mathrm{PPh}_{3}$ was added in one portion. The solution was stirred for $2 \mathrm{~h}$ at room 
temperature followed by filtering it through $\mathrm{Hyflo}^{\circledR}$ Super-Cel ${ }^{\circledR}$ filter aid. The solvent was removed by evaporation under vacuum yielding a sticky residue which was kept overnight in the freezer compartment of a refrigerator. Next day the solid was washed with diethyl ether $(3 \times 5 \mathrm{~mL})$ and triturated with small portions of cold diethyl ether until it solidified giving 7 as orange yellow powder. Dried under argon. Yield $37.5 \mathrm{mg}(77 \%)$. The product can be recrystallized from $\mathrm{CH}_{2} \mathrm{Cl}_{2}$ by layering hexane on top of the solution. Elemental analysis (as $\mathrm{PF}_{6}$ salt, 7.PF $; \%$ ). Found: $\mathrm{C}, 51.93 ; \mathrm{H}, 4.86 ; \mathrm{N}, 3.35$; Calculated for $\mathrm{C}_{34} \mathrm{H}_{39} \mathrm{~N}_{2} \mathrm{P}_{2} \mathrm{ClF}_{6} \mathrm{Ru}$ : C, $51.81 ; \mathrm{H}, 4.99 ; \mathrm{N}, 3.55 \%$.

ESI-MS $\left(\mathrm{CH}_{3} \mathrm{OH}\right): \mathrm{m} / \mathrm{z} 643.160\left([\mathrm{M}]^{+}\right.$, calc. 643.158); correct isotope distribution pattern (Figure S21).

${ }^{1} \mathrm{H}$ NMR (400 MHz, $298 \mathrm{~K}, \mathrm{CD}_{2} \mathrm{Cl}_{2}$ ) $\delta / p p m 1.00$ (d, 6H, $\left.\mathrm{CH}_{3}-\mathrm{CH}-\mathrm{CH}_{3}\right), 1.31$ (t, 3H, N$\mathrm{CH}_{2} \mathrm{CH}_{3}$ ), 1.75 (s, 3H, C-CH $\mathrm{CH}_{3}, 2.36$ (heptet, $1 \mathrm{H}, \mathrm{CH}_{3}-\mathrm{CH}-\mathrm{CH}_{3}$ ), 3.06 (s, 3H, N-CH $)_{3}, 4.06$ (quartet, 2H, N-CH $\mathrm{CH}_{3}$ ), 5.65-5.90 (m, 4H, -CH-), 6.93 (d, 1H, N-CH=CH-N), $7.20(\mathrm{~d}, 1 \mathrm{H}$, $\mathrm{N}-\mathrm{CH}=\mathrm{CH}-\mathrm{N})$, 7.20-7.72 (m, 15H, $\left.\mathrm{PP} h_{3}\right)$ (Figure S18).

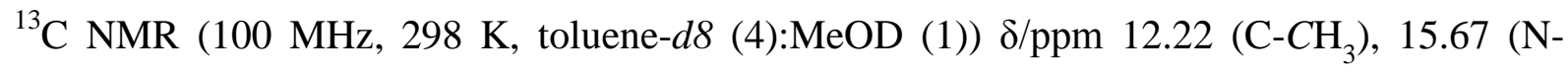
$\left.\mathrm{CH}_{2} \mathrm{CH}_{3}\right), 20.57\left(\mathrm{CH}-\mathrm{CH}_{3}\right), 28.62\left(\mathrm{CH}-\mathrm{CH}_{3}\right), 37.73\left(\mathrm{~N}-\mathrm{CH}_{3}\right), 45.34\left(\mathrm{~N}-\mathrm{CH}_{2}\right), 86.17,87.97$, 88.17, $90.94(\mathrm{CH}-\mathrm{CH}), 105.34\left(C-\mathrm{CH}_{3}\right), 113.44\left(\mathrm{CH}-\mathrm{CH}\left(\mathrm{CH}_{3}\right)_{2}\right), 122.76,123.08(\mathrm{~N}-\mathrm{CH}=\mathrm{CH}-$ $\mathrm{N}), 128.88\left(\mathrm{~d},{ }^{3} J_{\mathrm{P}-\mathrm{C}}=9.7 \mathrm{~Hz}, \mathrm{Ph}\right.$, meta $), 130.66\left(\mathrm{~d},{ }^{2} J_{\mathrm{P}-\mathrm{C}}=9.7 \mathrm{~Hz}, \mathrm{Ph}\right.$, ortho $), 130.95(\mathrm{~s}, \mathrm{Ph}$, para $), 132.46\left(\mathrm{~d},{ }^{1} J_{\mathrm{P}-\mathrm{C}}=19.4 \mathrm{~Hz}, \mathrm{Ph}\right.$, ipso $), 165.43\left(\mathrm{~d},{ }^{2} J_{\mathrm{P}-\mathrm{C}}=19.7 \mathrm{~Hz} \mathrm{NCN}\right), 165.63\left(\mathrm{~d},{ }^{2} J_{\mathrm{P}-\mathrm{C}}=\right.$ 19.7 Hz NCN) (Figure S19).

${ }^{31} \mathrm{P}\left\{{ }^{1} \mathrm{H}\right\} \mathrm{NMR}\left(145 \mathrm{MHz}, 298 \mathrm{~K}, \mathrm{CD}_{2} \mathrm{Cl}_{2}\right.$ ) $\delta / \mathrm{ppm} 24.57$ (s), 31.94 (s), 32.94 (s) (Figure S20).

Synthesis of $\left[\operatorname{RuCl}(\mathrm{emim})\left(\eta^{6}-p\right.\right.$-cymene $)(\mathbf{p t a}] \mathrm{Cl}(\mathbf{8})($ Procedure $\mathrm{S} 1.5)$

Complex 8 was prepared according to the procedure given above for 7 in reaction of $90 \mathrm{mg}$ $(0.216 \mathrm{mmol})\left[\mathrm{RuCl}_{2}(\mathrm{emim})\left(\eta^{6}-p\right.\right.$-cymene $\left.)\right]$ (4) and $34.1 \mathrm{mg}(0.216 \mathrm{mmol})$ 1,3,5-triaza-7- 
phosphaadamantane (pta). Orange yellow powder. Yield $95 \mathrm{mg}$ (77\%). The product can be purified by recrystallization from $0.1 \mathrm{M} \mathrm{HCl}$ by layering ethanol on top of the aqueous phase. Elemental analysis (\%): Found: C, 44.13; H, 6.52; N, 10.83; Calculated for $\mathrm{C}_{22} \mathrm{H}_{36} \mathrm{PN}_{5} \mathrm{Cl}_{2} \mathrm{Ru}$ : C, 46.07; H, 6.33; N, 12.21. Despite our efforts we were unable to obtain samples with more correct elemental analysis data and the composition of the product was established on basis of NMR, MS and X-ray diffraction analyses.

ESI-MS $\left(\mathrm{CH}_{3} \mathrm{OH}\right): \mathrm{m} / \mathrm{z} 538.143\left([\mathrm{M}]^{+}\right.$, calc. 538.144); correct isotope distribution pattern (Figure S27) .

${ }^{1} \mathrm{H}$ NMR $\left(400 \mathrm{MHz}, 298 \mathrm{~K}, \mathrm{CD}_{2} \mathrm{Cl}_{2}\right) \delta / \mathrm{ppm} 1.12\left(\mathrm{~d}, 6 \mathrm{H}, \mathrm{CH}_{3}-\mathrm{CH}-\mathrm{CH}_{3}\right), 1.36(\mathrm{t}, 3 \mathrm{H}, \mathrm{N}-$ $\mathrm{CH}_{2} \mathrm{CH}_{3}$ ), 1.93 (s, 3H, C-CH${ }_{3}$ ), 2.51 (heptet, $1 \mathrm{H}, \mathrm{CH}_{3}-\mathrm{CH}-\mathrm{CH}_{3}$ ), 3.30 (s, 3H, N-CH$)_{3}$ ), 4.12 (quartet, $\left.2 \mathrm{H}, \mathrm{N}-\mathrm{CH}_{2} \mathrm{CH}_{3}\right), 4.32\left(\mathrm{~m}, 6 \mathrm{H}, \mathrm{PCH}_{2} \mathrm{~N}\right), 4.36\left(\mathrm{~m}, 6 \mathrm{H}, \mathrm{NCH}_{2} \mathrm{~N}\right), 5.70(\mathrm{~d}, 1 \mathrm{H},-\mathrm{CH}-)$, $5.85(\mathrm{~d}, 1 \mathrm{H},-\mathrm{CH}-), 6.17(\mathrm{~d}, 1 \mathrm{H},-\mathrm{CH}-), 6.27(\mathrm{~d}, 1 \mathrm{H},-\mathrm{CH}-), 7.17-7.35(\mathrm{~m}, 2 \mathrm{H}, \mathrm{N}-\mathrm{CH}=\mathrm{CH}-\mathrm{N})$ (Figure S24).

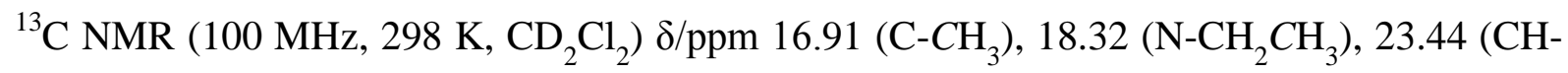
$\left.\mathrm{CH}_{3}\right), 31.21\left(\mathrm{CH}_{-}-\mathrm{CH}_{3}\right), 40.33\left(\mathrm{~N}-\mathrm{CH}_{3}\right), 46.79\left(\mathrm{~N}-\mathrm{CH}_{2}\right), 52.32\left(\mathrm{~d},{ }^{1} J_{\mathrm{P}-\mathrm{C}}=17 \mathrm{~Hz}, \mathrm{PCH} \mathrm{H}_{2} \mathrm{~N}\right)$, $72.93\left(\mathrm{~d},{ }^{3} \mathrm{JP}_{\mathrm{P}-\mathrm{C}}=6 \mathrm{~Hz}, \mathrm{NCH}_{2} \mathrm{~N}\right), 87.21,87.77,90.67,91.80(\mathrm{CH}-\mathrm{CH}), 102.69\left(\mathrm{C}-\mathrm{CH}_{3}\right), 114.30$ $\left(\mathrm{CH}-\mathrm{CH}\left(\mathrm{CH}_{3}\right)_{2}\right), 123.40,123.98(\mathrm{~N}-\mathrm{CH}=\mathrm{CH}-\mathrm{N}), 168.91,169.12,169.39(\mathrm{NCN})$ (Figure S25).

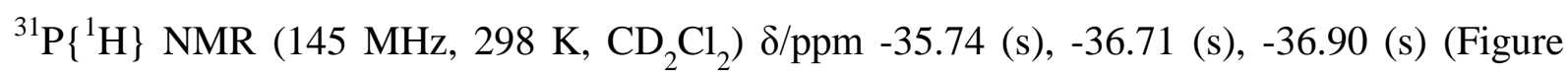
S26).

\subsection{General procedure for catalytic racemization}

All reactions were run under argon in Schlenk flasks. The solid Ru-NHC-complex (and the additional ligand, if any) were placed into the flask followed by $0.5 \mathrm{~mL}$ toluene and the optically active secondary alcohol. The flask was immersed into a bath of $80^{\circ} \mathrm{C}$ temperature for $10 \mathrm{~min}$ then cooled and a solution of the applied base in $1.5 \mathrm{~mL}$ toluene was added. This reaction mixture was heated in a thermostated bath for the desired reaction time then cooled to 
room temperature. Samples diluted by toluene and filtered through Hyflo ${ }^{\circledR}$ Super-Cel ${ }^{\circledR}$ were subjected to GC analysis (Procedure S2). Enantiomeric excess data (ee\%) were determined as an average of 3-5 experiments with a reproducibility of $\pm 3 \%$.

\section{Results and discussion}

\subsection{Synthesis and structure}

In this work we have synthetized several new ruthenium(II) complexes with the general composition of $\left[\mathrm{RuCl}_{2}(\mathrm{NHC})\left(\eta^{6}\right.\right.$-arene $\left.)\right]$ (4-6; $\mathrm{NHC}=$ bmim or emim; arene=benzene or $p$ cymene $)$ as well as of $\left[\mathrm{RuCl}(\mathrm{emim})\left(\eta^{6}-p\right.\right.$-cymene $\left.)\left(\mathrm{PR}_{3}\right)\right] \mathrm{Cl}\left(\mathbf{7}, \mathbf{8} ; \mathrm{PR}_{3}=\mathrm{PPh}_{3}\right.$ or pta). For crystallographic purposes $\mathrm{PF}_{6}^{-}$salt of $7\left(7 . \mathrm{PF}_{6}\right)$ was also obtained while $\mathbf{8}$ could be crystallized only as a $\mathrm{BF}_{4}^{-}$salt $\left(\mathbf{8}^{-B_{4}}\right)$. The syntheses of 4-6 involved carbene transfer to $\left[\left\{\mathrm{RuCl}_{2}\left(\eta^{6} \text {-arene }\right)\right\}_{2}\right]$ from the appropriate $\left[\mathrm{Ag}(\mathrm{NHC})_{2}\right]\left[\mathrm{AgCl}_{2}\right]$ complex obtained in reaction of $\mathrm{Ag}_{2} \mathrm{O}$ and the respective imidazolium chloride. The mixed-ligand NHC-phosphine complexes, 7 and $\mathbf{8}$ were prepared by substitution of one chloride ligand in $\left[\mathrm{RuCl}_{2}(\mathrm{emim})\left(\eta^{6}-\right.\right.$ p-cymene)] (4) by triphenylphosphine and 1,3,5-triaza-7-phosphatricyclo[3.3.1.1] $]^{3,7}$ decane (pta), respectively (Scheme 2). All new complexes were characterized by elemental analysis, ${ }^{1} \mathrm{H},{ }^{13} \mathrm{C}$, and ${ }^{31} \mathrm{P}$ NMR spectroscopies, ESI-MS spectrometry and single crystal X-ray diffraction.
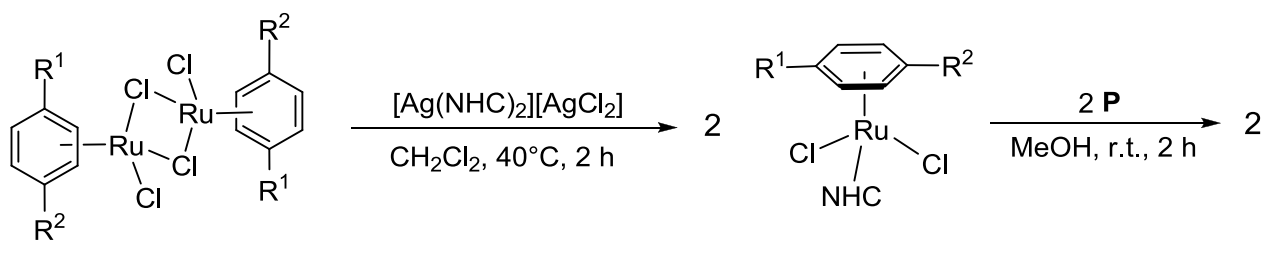<smiles>[R]c1ccc([R])c([R](C)(N)Cl)c1</smiles>

$$
R^{1}=R^{2}=H
$$

$\mathrm{R}^{1}=\mathrm{CH}_{3}$ and $\mathrm{R}^{2}={ }^{i} \mathrm{Pr}$
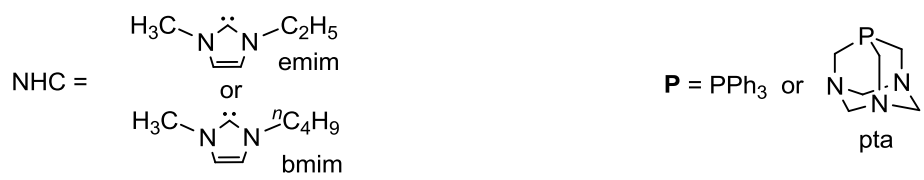

pta

Scheme 2. Synthesis of complexes 4-8 
The new complexes are orange yellow solids well soluble in $\mathrm{CH}_{2} \mathrm{Cl}_{2}$ and toluene, slightly soluble in $\mathrm{MeOH}$ and $\mathrm{EtOH}$ and insoluble in hexane. Except 7, they are also slightly soluble in water, although dissolution of 4-6 may be due to $\mathrm{Cl}^{-} / \mathrm{H}_{2} \mathrm{O}$ ligand exchange [21] yielding cationic aquacomplexes. According to spectroscopic and X-ray diffraction data 4-8 have three-legged piano-stool structures with the arene ring occupying three coordination sites around the $\mathrm{Ru}(\mathrm{II})$ ion.

The elemental analysis data of the $\left[\mathrm{RuCl}_{2}(\mathrm{NHC})\left(\eta^{6}\right.\right.$-arene) $)$ complexes (4-6) were in agreement with their suggested formulae. However, despite our efforts (analysis of several independently prepared samples, purification by chromatography, attempted recrystallizations, modifications of combustion analysis conditions), 7 and $\mathbf{8}$ (containing $\mathrm{PPh}_{3}$ and pta, respectively) gave consistently lower $\mathrm{C} \%$ values than expected (analysis of $\mathbf{8}$ was low also on $\mathrm{N} \%$ ). In contrast to $\mathbf{4}, \mathbf{5}$, and $\mathbf{6}$, the phosphine-containing complexes $\mathbf{7}$ and $\mathbf{8}$ were notoriously hard to crystallize, too. Nevertheless, compositions and structures of $\mathbf{7}$ and $\mathbf{8}$ could be unambiguously determined on the basis of spectroscopic and X-ray diffraction measurements.

Similar to earlier observations with $\left[\mathrm{RuCl}(\mathrm{bmim})\left(\eta^{6}-p\right.\right.$-cymene $\left.)(\mathrm{pta})\right] \mathrm{Cl}[25],{ }^{31} \mathrm{P}$ NMR spectra of 7 and $\mathbf{8}$ showed two major resonances in $\mathrm{CD}_{2} \mathrm{Cl}_{2}$ solutions at $\delta=31.94$ and $32.94 \mathrm{ppm}$, and at $\delta=-36,71$ and $-36.90 \mathrm{ppm}$, respectively (Figures S20 and S26). (The small intensity signal at $\delta=-35.74 \mathrm{ppm}$ in the ${ }^{31} \mathrm{P}$ NMR spectrum of 8 can be attributed to $\left[\mathrm{RuCl}_{2}\left(\eta^{6}-\right.\right.$ p-cymene)(pta)] formed by replacement of an emim ligand in $\mathbf{4}$ by pta during synthesis; a similar observation was made in synthesis of $\left[\mathrm{RuCl}(\mathrm{bmim})\left(\eta^{6}-p\right.\right.$-cymene $\left.)(\mathrm{pta})\right] \mathrm{Cl}$ from $\left[\mathrm{RuCl}_{2}(\mathrm{bmim})\left(\eta^{6}-p\right.\right.$-cymene $\left.)\right]$ and pta [25].) The two ${ }^{31} \mathrm{P}$ NMR signals were observed for 7 and $\mathbf{8}$ in several solvents $\left(\mathrm{CDCl}_{3}, \mathrm{DMSO}, \mathrm{D}_{2} \mathrm{O}\right)$ and their relative intensities did not change significantly on variations in temperature or on addition of $\mathrm{KCl}\left(\mathrm{D}_{2} \mathrm{O}\right)$, making the presence of a mobile dissociation equilibrium of any of the ligands unlikely. Conversely, the congested 
coordination spheres of $\mathbf{7}$ and $\mathbf{8}$ may allow existence of isomeric structures and we attempted to look closer at this possibility by theoretical calculations.

\subsubsection{DFT calculations on the possible structures of 7 in solution}

In order to get deeper understanding of the possible existence of various structural isomers in solution, DFT calculations were done to compare the energies of the possible isomers of the $\left[\mathrm{RuCl}(\mathrm{emim})\left(\eta^{6}-p \text {-cymene }\right)\left(\mathrm{PPh}_{3}\right)\right]^{+}$complex ion (as in 7).

Four effects were analyzed: the orientation of $p$-cymene and carbene, as well as the rotation of the ethyl group of the carbene and the propyl group of the $p$-cymene, respectively. Repulsion of the methyl and ethyl groups together with steric hindrances play important role in the relative stability of the possible isomers of the complex.

There are four orientations of the $p$-cymene ligand and two orientations of the carbene ligand what results in eight possible isomers Since the ethyl group of the carbene and the 2propyl group of the $p$-cymene can also rotate the number of the possible isomers increases to 32. However, due to steric hindrance only eight of these can be reasonably expected to appear in solution (structures 1-8, Figure S30). Relative energies of these isomers derived from Boltzmann distribution are collected in Table S3.
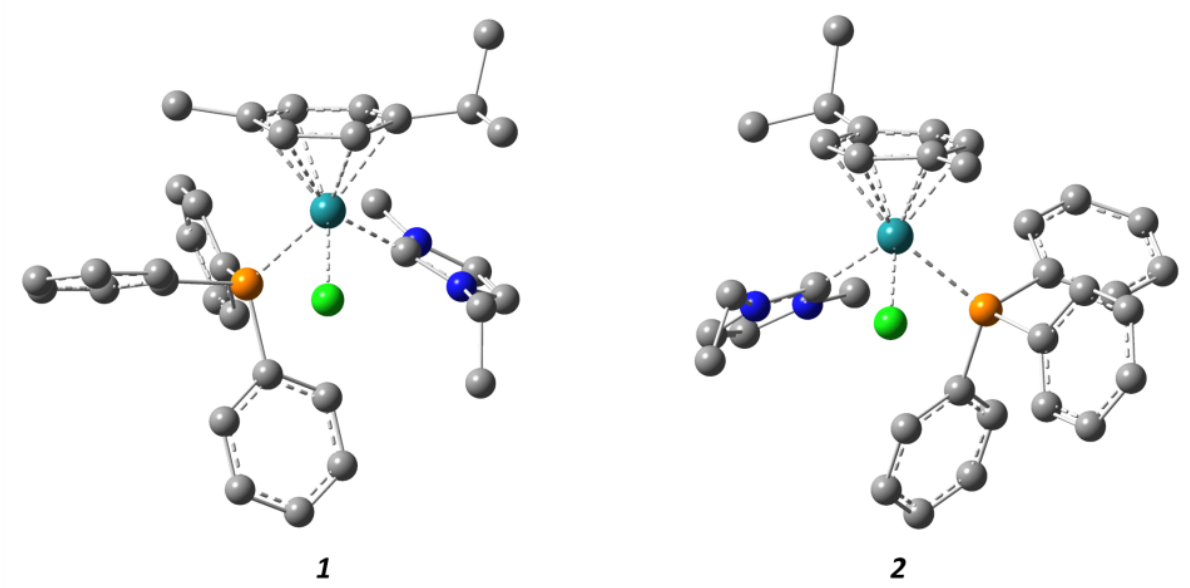

Figure 1. The most probable isomers in solutions of $\left[\mathrm{RuCl}(\mathrm{emim})\left(\eta^{6}-p \text {-cymene }\right)\left(\mathrm{PPh}_{3}\right)\right]^{+}$as revealed by DFT calculations 
Both the B3LYP and M06 single point calculations give high probabilities of presence in the isomeric mixture for 1 and 2, while from the $5 / 6$ isomer pair a probable presence of 5 is indicated by calculations with the M06, and that of 6 with the B3LYP functionals. Altogether these theoretical calculations reveal that the various possible isomers may be present in widely different concentrations in the solutions of complexes with $\left(\eta^{6}\right.$-arene $) \mathrm{Ru}(\mathrm{NHC})\left(\mathrm{PR}_{3}\right)$ moieties and that in case of $\left[\mathrm{RuCl}(\mathrm{emim})\left(\eta^{6}-p \text {-cymene }\right)\left(\mathrm{PPh}_{3}\right)\right]^{+}$the most likely species to be observed are 1 and 2 (Figure 1). Although experimentally determined solid state structures and theoretically calculated geometries for complex ions in solution cannot be directly compared, it is tempting to mention that the X-ray structure of 7 (Figure 3) shows a close fit with structure of isomer 2 (Figure 1).

\subsubsection{Solid state structures of 4-7}

Complexes 4-7 were examined by single crystal X-ray crystallography and the results showed unambigously the expected pseudo-octahedral three-legged piano stool geometries. ORTEP diagrams of $\mathbf{6}$ and 7 (Figures $\mathbf{2}$ and 3 ) are representative examples for the other $\left[\mathrm{RuCl}_{2}\left(\eta^{6}-\right.\right.$ arene)(NHC)] and $\left[\mathrm{RuCl}\left(\eta^{6}\right.\right.$-arene $)(\mathrm{NHC})($ phosphine $\left.)\right]$ complexes, too. In general, the structural features (respective bond lenghts and angles) are close to those found in the literature for similar compounds $[64,65]$. (In the literature, there are only two Ru(II)-areneNHC-phosphine half-sandwich complexes structurally characterized in solid state, namely $\left[\mathrm{RuCl}\left(\mathrm{Bn}_{2}\right.\right.$-bimy $)\left(\eta^{6}-p\right.$-cymene $\left.)\left(\mathrm{PPh}_{3}\right)\right]\left[\mathrm{PF}_{6}\right] \quad$ and $\quad\left[\mathrm{RuCl}\left({ }^{\mathrm{i}} \mathrm{Pr}-\mathrm{Bn}\right.\right.$-bimy $)\left(\eta^{6}-p-\right.$ cymene) $\left.\left(\mathrm{PPh}_{3}\right)\right]\left[\mathrm{PF}_{6}\right] \quad$ (bimy=benzimidazolin-2-ylidene) [65]). Detailed analysis of the structural data can be found in the Supporting Information. 


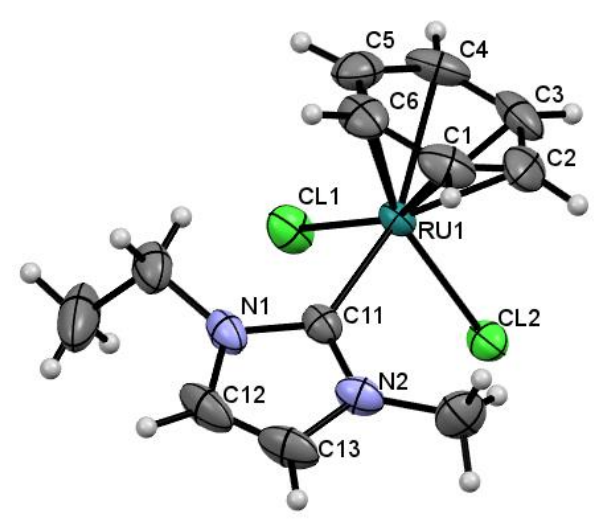

Figure 2. ORTEP diagram of $\left[\mathrm{RuCl}_{2}(\mathrm{emim})\left(\eta^{6}\right.\right.$-benzene $\left.)\right](\mathbf{6})$ with thermal ellipsoids shown at $50 \%$ probability level. Selected bond lengths $[\AA]$ and bond angles [deg]: Ru1$\mathrm{C} 11=2.065(2), \quad \mathrm{Ru} 1-\mathrm{Cl} 1=2.4173(7), \quad \mathrm{Ru} 1-\mathrm{Cl} 2=2.4270(7), \quad \mathrm{C} 12-\mathrm{C} 13=1.318(5), \quad \mathrm{Ru}-$ $\operatorname{ar}_{\text {centroid }}=1.691$, Ru1-C1 =2.161(2), Ru1-C2=2.161(2), Ru1-C3=2.242(2), Ru1-C4=2.254(3), Ru1-C5=2.168(3), Ru1-C6=2.174(3); Cl1-Ru1-Cl2=84.31(2), Cl1-Ru1-C11=90.61(7), Cl2Ru1-C11=89.60(7).

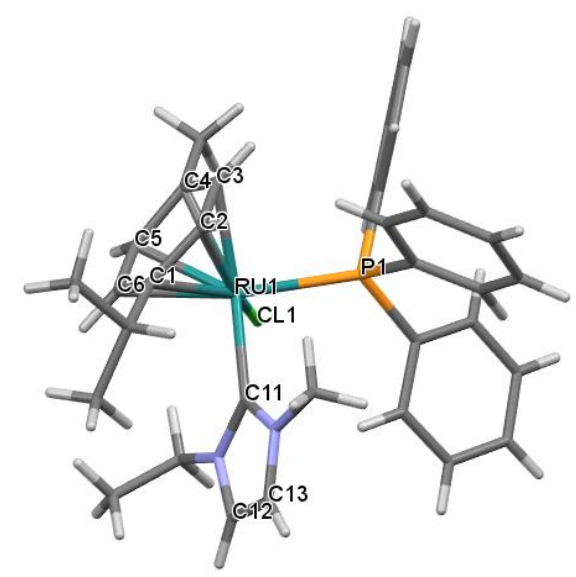

Figure 3. Capped sticks structure of $\left[\mathrm{RuCl}(\mathrm{emim})\left(\eta^{6}-p \text {-cymene }\right)\left(\mathrm{PPh}_{3}\right)\right]^{+}$(in $7 . \mathrm{PF}_{6}^{-} ; \mathrm{PF}_{6}^{-}$is omitted for clarity). See Figure S19 for an ORTEP diagram of the complex with thermal ellipsoids shown at 50\% probability level. Selected bond lengths $[\AA]$ and bond angles [deg]: Ru1-C11=2.086(5), Ru1-Cl1=2.4007(11), Ru1-P1=2.3885(11), C12-C13=1.322(15) Ru$\mathrm{ar}_{\text {centroid }}=1.691, \mathrm{Ru} 1-\mathrm{C} 1=2.272(4), \mathrm{Ru} 1-\mathrm{C} 2=2.229(4), \mathrm{Ru} 1-\mathrm{C} 3=2.231(4), \mathrm{Ru} 1-\mathrm{C} 4=2.285(4)$, Ru1-C5=2.208(5), Ru1-C6=2.245(5); Cl1-Ru1-P1= 94.0(2), Cl1-Ru1-C11= 91.29(15), P1$\mathrm{Ru} 1-\mathrm{Cl1}=79.18(4)$. 


\subsection{Catalytic racemization of secondary alcohols}

The new half-sandwich (arene)Ru(II)-NHC and (arene)Ru(II)-NHC-phosphine complexes were studied as catalysts in racemization of $(S)$-1-phenylethanol (Scheme 1). As mentioned in the Introduction the catalytic racemization requires a base to proceed - most probably the base assists the formation of catalytically active $\mathrm{Ru}(\mathrm{II})$-hydrides in reaction of the $\mathrm{Ru}(\mathrm{II})$ catalyst and the alcohol (or solvent). In general, racemization is accompanied by (unwelcome) formation of the corresponding ketone (acetophenone in case of (S)-1-phenylethanol), and the extent of ketone formation is also influenced by the quality and quantity of the applied base. Several bases were screened for their effect on catalysis of $(S)$-1-phenylethanol racemization catalyzed by $\left[\mathrm{RuCl}_{2}(\mathrm{bmim})\left(\eta^{6}-p\right.\right.$-cymene)] (3) (conditions in the footnote to Table 1$)$. In the absence of a base the reaction did not proceed at all, while the use of $\mathrm{KOH}, \mathrm{NaOH}$ and ${ }^{t} \mathrm{BuOK}$ led to formation of black precipitates. Conversely, in the presence of $\mathrm{HCOONa}$ or $(\mathrm{Et})_{3} \mathrm{~N}$ the reaction mixtures remained homogeneous. The use of $\mathrm{HCOONa}$ allowed almost complete racemization in $4 \mathrm{~h}$ (enantiomeric excess of the resulting $(S)$-1-phenylethanol was as low as $1.3 \%$ with $20.4 \%$ acetophenone formation). In contrast, $(\mathrm{Et})_{3} \mathrm{~N}$ led to $53.4 \%$ ee and $45.4 \%$ acetophenone. For this reason HCOONa was used as base throughout the rest of this study.

Table 1 shows the results of catalytic racemizations with various $\mathrm{Ru}(\mathrm{II})-\mathrm{NHC}$ complexes. Previously known complexes, such as eg $\mathbf{1}$ or $\mathbf{3}$ were also applied as catalysts. In several cases the catalysts were prepared in situ in reaction of $\mathbf{1}$ or $\mathbf{3}$ with NHC or tertiary phosphine $\left(\mathrm{PPh}_{3}\right.$, pta) ligands. The reactions run smoothly in various solvents at $95^{\circ} \mathrm{C}$. 
Table 1. Catalytic activity of $\mathrm{Ru}(\mathrm{II})$-(NHC) complexes in racemization of (S)-1phenylethanol. ${ }^{\mathrm{a}}$

\begin{tabular}{|c|c|c|c|c|}
\hline Entry & Catalyst & Added ligand & $\begin{array}{l}e e \\
(\%)\end{array}$ & $\begin{array}{c}\text { Acetophenone } \\
(\%)\end{array}$ \\
\hline 1 & None & - & 99.9 & 0 \\
\hline 2 & {$\left[\left\{\mathrm{RuCl}_{2}\left(\eta^{6}-p \text {-cymene }\right)\right\}_{2}\right] \mathbf{1}$} & - & 96.5 & 4.9 \\
\hline 3 & {$\left[\left\{\mathrm{RuCl}_{2}\left(\eta^{6}-p \text {-cymene }\right)\right\}_{2}\right] \mathbf{1}$} & $2 \mathrm{PPh}_{3}$ & 77.6 & 9.5 \\
\hline 4 & {$\left[\left\{\mathrm{RuCl}_{2}\left(\eta^{6}-p \text {-cymene }\right)\right\}_{2}\right] \mathbf{1}$} & $2 \mathrm{IMes} . \mathrm{HCl}$ & 52.7 & 8.4 \\
\hline 5 & {$\left[\left\{\mathrm{RuCl}_{2}\left(\eta^{6}-p \text {-cymene }\right)\right\}_{2}\right] \mathbf{1}$} & 2 SIMes.HCl & 53.3 & 17.5 \\
\hline 6 & {$\left[\left\{\mathrm{RuCl}_{2}\left(\eta^{6}-p \text {-cymene }\right)\right\}_{2}\right] \mathbf{1}$} & $2 \mathrm{bmim} . \mathrm{HCl}$ & 4.1 & 20.6 \\
\hline 7 & {$\left[\mathrm{RuCl}_{2}(\mathrm{bmim})\left(\eta^{6}-p\right.\right.$-cymene $\left.)\right] \mathbf{3}$} & - & 18.5 & 16.0 \\
\hline 8 & {$\left[\mathrm{RuCl}_{2}(\mathrm{bmim})\left(\eta^{6}-p\right.\right.$-cymene $\left.)\right] \mathbf{3}$} & $\mathrm{PPh}_{3}$ & 1.3 & 20.4 \\
\hline 9 & {$\left[\mathrm{RuCl}_{2}(\mathrm{bmim})\left(\eta^{6}-p\right.\right.$-cymene $\left.)\right] \mathbf{3}$} & $\mathrm{PPh}_{3}$ & 3.4 & $3.5^{\mathrm{b}}$ \\
\hline 10 & {$\left[\mathrm{RuCl}_{2}\left(\eta^{6}-p\right.\right.$-cymene $\left.)(\mathrm{pta})\right]$} & - & 89.1 & $4.6^{\mathrm{c}}$ \\
\hline 11 & {$\left[\mathrm{RuCl}_{2}(\mathrm{bmim})\left(\eta^{6}-p\right.\right.$-cymene $\left.)\right] \mathbf{3}$} & pta & 84.3 & $3.7^{\mathrm{c}}$ \\
\hline 12 & {$\left[\mathrm{RuCl}_{2}(\mathrm{emim})\left(\eta^{6}-p\right.\right.$-cymene $\left.)\right] 4$} & - & 24.7 & $9.7^{\mathrm{d}}$ \\
\hline 13 & {$\left[\mathrm{RuCl}_{2}(\mathrm{emim})\left(\eta^{6}-p\right.\right.$-cymene $\left.)\right] 4$} & - & 47.1 & $2.4^{\mathrm{b}}$ \\
\hline 14 & {$\left[\mathrm{RuCl}(\mathrm{emim})\left(\eta^{6}-p\right.\right.$-cymene $\left.)\left(\mathrm{PPh}_{3}\right)\right] \mathrm{Cl} 7$} & - & 28.7 & $5.3^{\mathrm{b}}$ \\
\hline 15 & {$\left[\mathrm{RuCl}(\mathrm{emim})\left(\eta^{6}-p\right.\right.$-cymene $\left.)(\mathrm{pta})\right] \mathrm{Cl} \mathbf{8}$} & - & 20.5 & $4.8^{\mathrm{b}}$ \\
\hline 16 & {$\left[\mathrm{RuCl}_{2}(\mathrm{bmim})\left(\eta^{6}\right.\right.$-benzene $\left.)\right] \mathbf{5}$} & - & 78.4 & $2.1^{\mathrm{e}}$ \\
\hline 17 & {$\left[\mathrm{RuCl}_{2}(\mathrm{emim})\left(\eta^{6}\right.\right.$-benzene $\left.)\right] \mathbf{6}$} & - & 84.7 & $1.6^{\mathrm{e}}$ \\
\hline
\end{tabular}

Conditions: ${ }^{\mathrm{a}} \mathrm{c}($ catalyst $)=0.01 \mathrm{M} ; \mathrm{c}($ ligand $)=0.01 \mathrm{M} ; \mathrm{c}((S)-1$-phenylethanol $)=0.252 \mathrm{M} ; \mathrm{c}(\mathrm{HCOONa})=0.1 \mathrm{M}$; solvent $=2 \mathrm{~mL}$ toluene; $\mathrm{t}=4 \mathrm{~h} ; \mathrm{T}=95^{\circ} \mathrm{C} ;{ }^{\mathrm{b}}$ solvent=toluene:isopropanol $=5: 1 ;{ }^{\mathrm{c}}$ solvent $=1 \mathrm{~mL}$ toluene $+1 \mathrm{~mL}$ $\mathrm{H}_{2} \mathrm{O}$; ${ }^{\mathrm{d}}$ solvent=2 $\mathrm{mL} \mathrm{CH} \mathrm{Cl}_{2}$; ${ }^{\mathrm{e}}$ solvent=1 $\mathrm{mL} \mathrm{H}_{2} \mathrm{O}+1 \mathrm{~mL}$ (toluene:isopropanol = 5:1). IMes. $\mathrm{HCl}=(1,3-b i s(2,4,6-$ trimethylphenyl)imidazolium chloride), SIMes. $\mathrm{HCl}=(1,3$-bis(2,4,6-trimethylphenyl)imidazolinium chloride). 
As can be seen from Table 1 , the reaction is genuinely catalytic in the $\mathrm{Ru}(\mathrm{II})$-complexes since in their absence (Entry 1) there was no racemization whatsoever. $\left[\left\{\mathrm{RuCl}_{2}\left(\eta^{6}-p \text {-cymene }\right)\right\}_{2}\right]$ (1) has only negligible catalytic activity (Entry 2), however in situ mixtures of 1 with $\mathrm{PPh}_{3}$ or imidazolium salts (Entries 2-6) catalyzed the racemization of (S)-1-phenylethanol with a final $e e$ of $77.6-4.1 \%$. Of particular interest is the high catalytic activity of the in situ prepared catalyst $1+\mathrm{bmim} . \mathrm{HCl}$ (Entry $6, e e=4.1 \%$ ). This finding is in agreement with the high catalytic activity of the isolated $\left[\mathrm{RuCl}_{2}(\mathrm{bmim})\left(\eta^{6}-p\right.\right.$-cymene) $)(3)$ (Entry $\left.7, e e=18.5 \%\right)$ and refers to formation of an (arene) RuCl(bmim) species as a catalytically important intermediate, probably facilitated by the basic conditions of the reaction. (Direct formation of M-NHC complexes from imidazolium salts and $\mathrm{Rh}(\mathrm{I})$ - [66] or $\mathrm{Ru}(\mathrm{II})$-complexes [67] is not unprecedented.) Addition of $\mathrm{PPh}_{3}$ to 3 further increased the catalytic activity (Entry 8), although formation of acetophenone was still extensive. Catalysts containing pta, emim as an NHC or benzene an $\eta^{6}$-arene ligand showed low to medium catalytic activity (ee=89.1-20.5\%) (Entries 10-17). Solvent effects were also observed (eg Entries 8 vs 9, 12 vs 13); these are discussed in more detail below. On the basis of the data in Table 3, most of the investigations were done with use of the most active $\left[\mathrm{RuCl}_{2}(\mathrm{bmim})\left(\eta^{6}-p\right.\right.$-cymene $\left.)\right](\mathbf{3})+\mathrm{PPh}_{3}$ in situ prepared catalyst.

Figure 4 shows the time course of $(S)$-1-phenylethanol racemization and that of the accompanying acetophenone formation upon catalysis by $\left[\mathrm{RuCl}_{2}(\mathrm{bmim})\left(\eta^{6}-p\right.\right.$-cymene $\left.)\right](\mathbf{3})+$ $\mathrm{PPh}_{3}$. It can be seen that meanwhile racemization proceeded steadily $(\Delta e e=65 \%$ in the first hour of the reaction) and was complete after $4 \mathrm{~h}$, the yield of acetophenone approached approximately $20 \%$. 


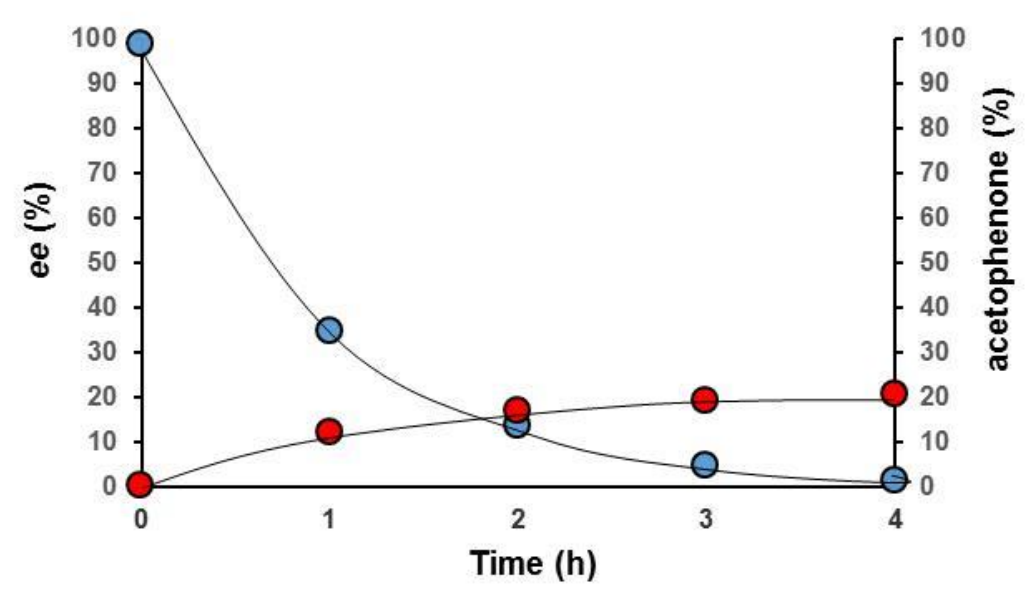

Figure 4. Time course of the racemization of $(S)$-1-phenylethanol $(\bullet)$ and that of the accompanying acetophenone $(\bullet)$ formation catalyzed by $\left[\mathrm{RuCl}_{2}(\mathrm{bmim})\left(\eta^{6}-p\right.\right.$-cymene $\left.)\right](\mathbf{3})+$ $\mathrm{PPh}_{3}$. Conditions: $\mathrm{c}(\mathbf{3})=0.01 \mathrm{M} ; \mathrm{c}\left(\mathrm{PPh}_{3}\right)=0.01 \mathrm{M} ; \mathrm{c}((S)-1-$ phenylethanol $)=0.252 \mathrm{M}$; $\mathrm{c}(\mathrm{HCOONa})=0.1 \mathrm{M} ;$ solvent $=2 \mathrm{~mL}$ toluene; $\mathrm{T}=95^{\circ} \mathrm{C}$.

An increase in the reaction temperature increased the rate of racemization (Figure 5). At $95^{\circ} \mathrm{C}$ the $e e$ was as low as $3.6 \%$ at $2 \mathrm{~h}$ and $1.3 \%$ at $4 \mathrm{~h}$ reaction time, and from the time course of the reaction an initial TOF $=9.3 \mathrm{~h}^{-1}$ could be calculated. 


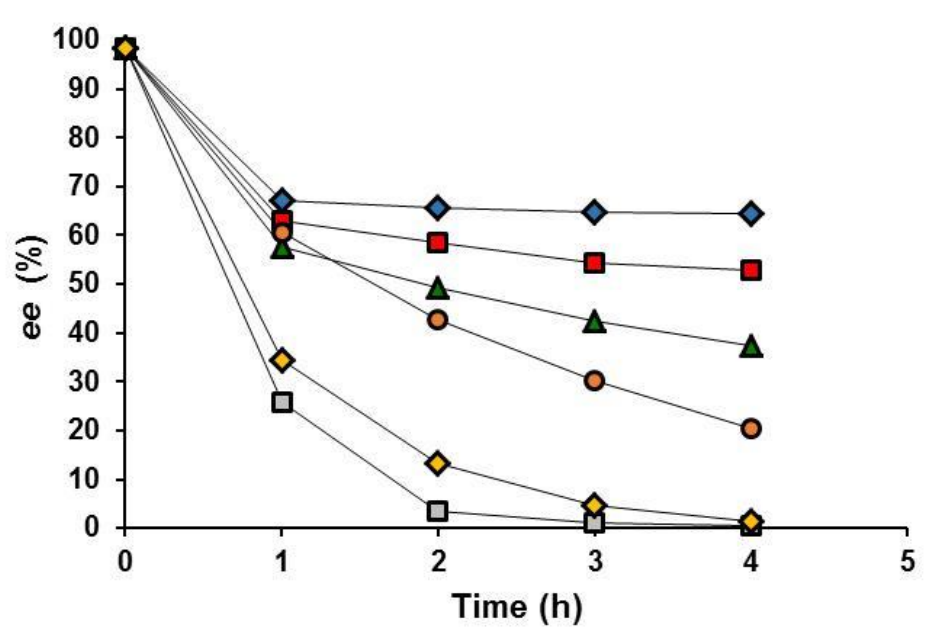

Figure 5. Racemization of (S)-1-phenylethanol catalyzed by $\left[\mathrm{RuCl}_{2}(\mathrm{bmim})\left(\eta^{6}-p\right.\right.$-cymene $\left.)\right](3)$ $+\mathrm{PPh}_{3}$; enantiomeric excess as a function of the time at different temperatures. Conditions: $\mathrm{c}(3)=0.01 \mathrm{M} ; \mathrm{c}\left(\mathrm{PPh}_{3}\right)=0.01 \mathrm{M} ; \mathrm{c}((S)-1-$ phenylethanol $)=0.252 \mathrm{M} ; \mathrm{c}(\mathrm{HCOONa})=0.1 \mathrm{M}$; solvent $=2 \mathrm{~mL}$ toluene; $\mathrm{t}=4 \mathrm{~h} ; \mathrm{T}=60^{\circ} \mathrm{C}(\diamond), 70^{\circ} \mathrm{C}(\bullet), 80^{\circ} \mathrm{C}(\Delta), 85^{\circ} \mathrm{C}(\bullet), 90^{\circ} \mathrm{C}(\diamond)$ and $95^{\circ} \mathrm{C}(\square)$

Formation of ketones during racemization leads to a loss of the often expensive secondary alcohol substrate and it is therefore desirable to keep it to a minimum level. We have found that in case of (arene) $\mathrm{Ru}(\mathrm{NHC})$-phosphine catalysts this can be achieved by proper choice of the solvent. Indeed, addition of isopropanol into reaction mixtures of $(S)$-1-phenylethanol racemization with $\mathbf{3}+\mathrm{PPh}_{3}$ catalyst, effectively suppressed acetophenone formation (Figure 6). The best results were obtained with a toluene:isopropanol 5:1 solvent which led to acetophenone formation as low as $3.5 \%$, while racemization was still close to complete $(e e=3.4 \%)$. In the presence of base, isopropanol is often used as an H-donor solvent for transfer hydrogenation of ketones [68, 69]; we assume that $\mathbf{3}$ catalyzed such transfer hydrogenation of any free acetophenone formed during the racemization process (Scheme 1) thereby keeping the yield of ketone byproduct low. 


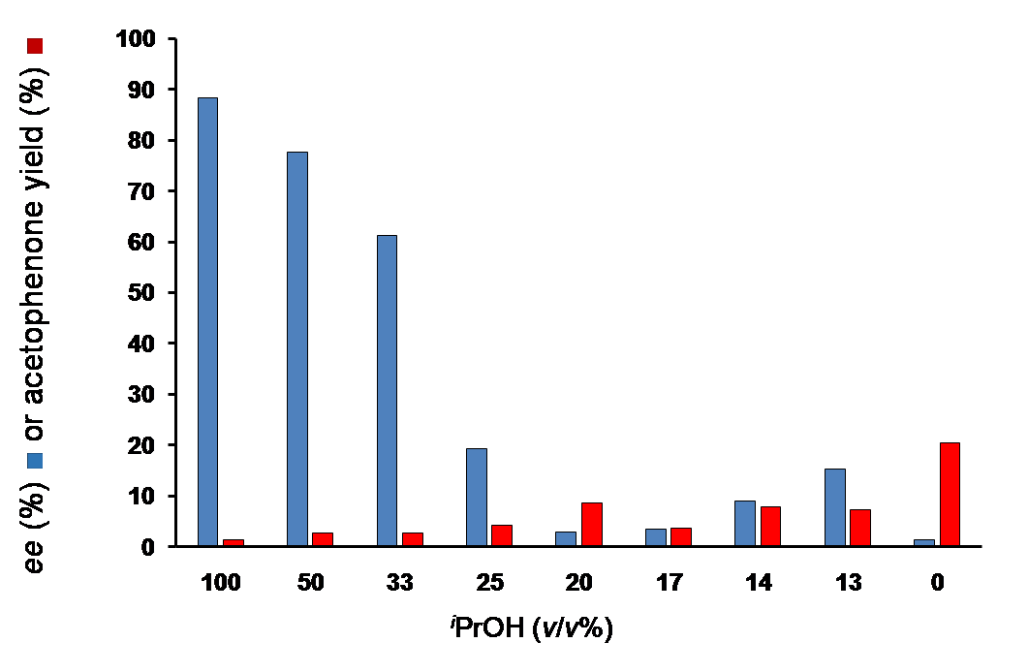

Figure 6. Solvent effect on racemization of (S)-1-phenylethanol ( $\square$ ) and concomitant formation of acetophenone ( $\square$ ) catalyzed by $\left[\mathrm{RuCl}_{2}(\mathrm{bmim})\left(\eta^{6}-p\right.\right.$-cymene $\left.)\right](\mathbf{3})+\mathrm{PPh}_{3}$. Conditions: $\mathrm{c}(\mathbf{3})=0.01 \mathrm{M} ; \mathrm{c}\left(\mathrm{PPh}_{3}\right)=0.01 \mathrm{M} ; \mathrm{c}((S)-1$-phenylethanol $)=0.252 \mathrm{M}$; $\mathrm{c}(\mathrm{HCOONa})=0.1 \mathrm{M} ;$ solvent $=2 \mathrm{~mL} ; \mathrm{t}=4 \mathrm{~h} ; \mathrm{T}=95^{\circ} \mathrm{C}$.

Racemization of other secondary alcohols, namely that of $(R)-(-)-2$-octanol and $(S)-(-)-\alpha-$ methyl-2-naphthalenemethanol was also investigated with the catalyst prepared in situ from $\mathbf{3}$ and $\mathrm{PPh}_{3}$. The results are shown on Figure 7. As can be seen, the fastest reaction was observed with $(S)$-1-phenylethanol while the lowest reactivity was shown by $(R)-(-)-2-$ octanol. These results indicate that the acidity of the alcohol molecule plays important role in the reaction mechanism. Indeed, the electron withdrawing phenyl substituent in $(S)$-1phenylethanol facilitates both deprotonation of the alcohol (and its subsequent coordination as an alkoxy ligand) and $\mathrm{H}$-abstraction from the chiral carbon to $\mathrm{Ru}$ - in contrast to a hexylgroup in $(R)$-(-)-2-octanol. While $(S)-(-)-\alpha$-methyl-2-naphthalenemethanol also has an 
aromatic substituent on the chiral carbon atom, its racemization is probably hindered by the steric requirements of the bulky naphthyl group.

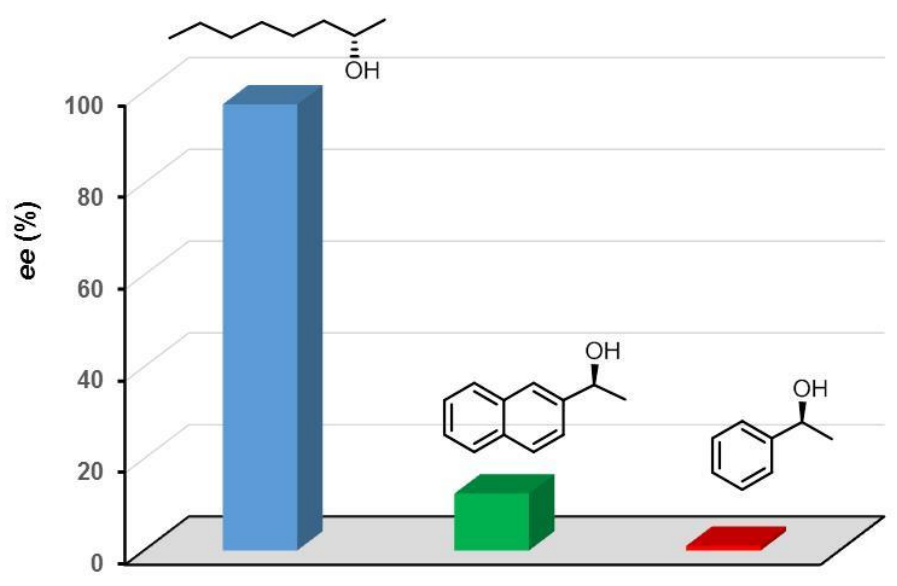

Figure 7. Racemization of (R)-(-)-2-octanol, $(S)$-(-)- $\alpha$-methyl-2-naphthalenemethanol, and $(S)$-1-phenylethanol catalyzed by $\left[\mathrm{RuCl}_{2}(\right.$ bmim $)\left(\eta^{6}-p\right.$-cymene $\left.)\right](3)+\mathrm{PPh}_{3}$. Conditions: $\mathrm{c}(\mathbf{3})=$ $0.01 \mathrm{M} ; \mathrm{c}\left(\mathrm{PPh}_{3}\right)=0.01 \mathrm{M} ; \mathrm{c}($ substrate $)=0.252 \mathrm{M} ; \mathrm{c}(\mathrm{HCOONa})=0.1 \mathrm{M} ;$ solvent $=2 \mathrm{~mL}$ toluene; $\mathrm{t}=4 \mathrm{~h} ; \mathrm{T}=95^{\circ} \mathrm{C}$.

The mechanism of racemization of $(S)$-1-phenylethanol was investigated by DFT calculations and the suggested multistep process is shown on Scheme 3. The $\left[\mathrm{Ru}(\mathrm{emim})\left(\eta^{6}-p-\right.\right.$ cymene $)]^{2+}$ fragment can be formed from $\left[\mathrm{RuCl}(\mathrm{emim})\left(\eta^{6}-p\right.\right.$-cymene $\left.)\left(\mathrm{PPh}_{3}\right)\right] \mathrm{Cl}(7)$ by loss of a coordinated $\mathrm{Cl}^{-}$and $\mathrm{PPh}_{3}$ due to steric congestion; subsequent coordination of the substrate alcohol (deprotonated by the base) then leads to A in the catalytic cycle. 


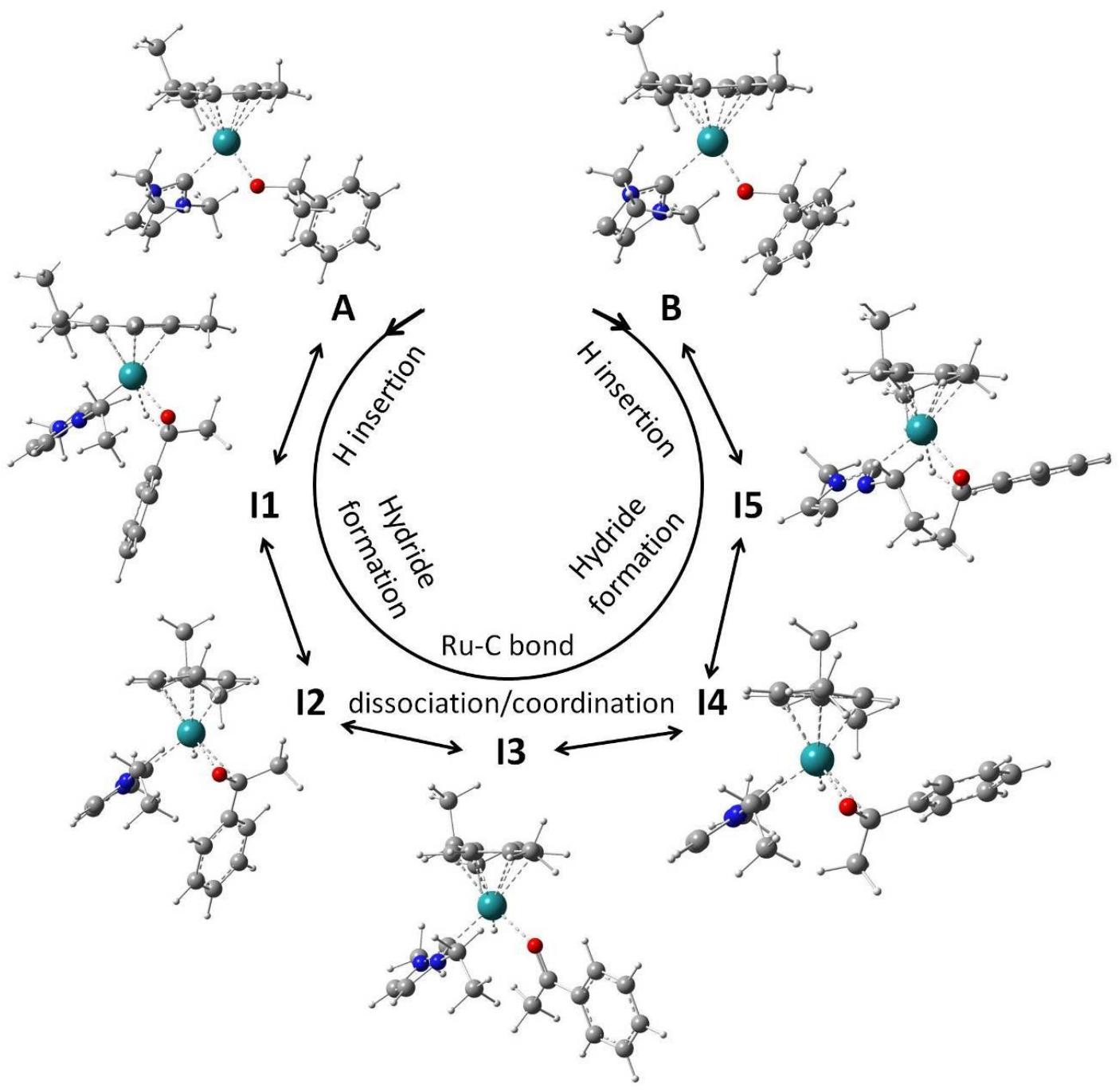

Scheme 3. Transition state (TS) geometries and intermediates (I) along the mechanistic pathway of racemization of $(S)$-1-phenylethanol catalyzed by $\left[\operatorname{RuCl}(\mathrm{emim})\left(\eta^{6}-p-\right.\right.$ cymene $\left.)\left(\mathrm{PPh}_{3}\right)\right] \mathrm{Cl}(7)$.

Coordination of the alcoholate results in a coordinatively unsaturated alkoxy-complex (A). The rate determining step (TS1) from this structure is the coordination of the hydrogen of the chiral carbon atom resulting in an energetically not favored agostic complex as intermediate (I1). In the next step (TS2) the hydrogen is transferred to the metal center giving a hydridoruthenium(II) complex with an $\eta^{2}$-CO-coordinated ketone (I2). The Ru-C bond can split easily (very low energy barrier, see below) and this leads to formation of an O-bound 
ketone (I3). (The amount of the undesired ketone side-product in racemization is determined by the ease with which the coordinated ketone leaves the ligand sphere of ruthenium and transfers to the bulk of the solution.) There is a chance the ketone in $\mathbf{I 3}$ coordinates again to $\mathrm{Ru}$ through an $\eta^{2}$-CO-bond, however, due to the free rotation around the $\mathrm{Ru}-\mathrm{O}$ bond this occasionally happens from the other side of the carbonyl group, resulting in formation of I4. Finally, transfer of hydrogen from Ru(II)-H to C2 via I5 yields B. Replacement of the product $(R)$-1-phenylethanol in $\mathbf{B}$ by its $(S)$-enantiomer drives the catalytic cycle towards formation of a racemic mixture.

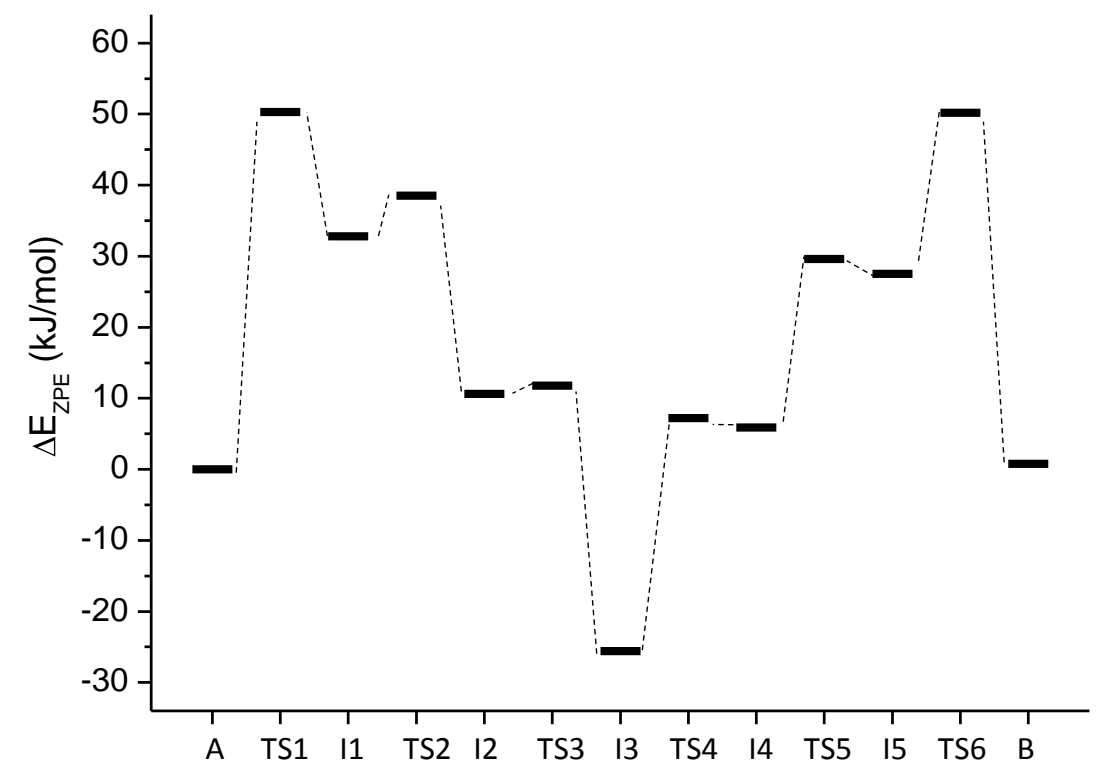

Figure 8. Energy profile of racemization of 1-phenylethanol catalyzed by the $\left[\operatorname{Ru}(\mathrm{emim})\left(\eta^{6}-\right.\right.$ p-cymene) $]^{2+}$ complex fragment.

The energy profile of the reaction (Figure 8) was also calculated. It clearly shows that the rate determining step of the reaction is the coordination of the hydrogen of the $\mathrm{C} 2$ chiral carbon $\left(\Delta \mathrm{E}_{\mathrm{ZPE}}=50 \mathrm{~kJ} / \mathrm{mol}\right)$ which yields $\mathbf{I} 1$ (Scheme 3$)$. This coordination is probably facilitated by coordination of the alkoxy oxygen in the preceding step. Abstraction of $\mathrm{H}$ by $\mathrm{Ru}$ from $\mathrm{C} 2$ proceeds with a much smaller barrier (TS2), furthermore, the resulting I2 ( $\eta^{2}$-carbonyl 
coordination) needs only very small activation energy to transform to the O-bound ketone (I3). This mechanism is also in accord with the observed order of reactivity of $(S)$-1phenylethanol, $(S)$-(-)- $\alpha$-methyl-2-naphthalenemethanol, and(R)-(-)-2-octanol (Figure 7).

\section{Summary}

New ( $\eta^{6}$-arene)Ru(II)-NHC, 4-6 and $\left(\eta^{6}\right.$-arene $) \mathrm{Ru}(\mathrm{II})-\mathrm{NHC}-\mathrm{PR}_{3}, \mathbf{7}, \mathbf{8}$ complexes were synthetized and characterized (elemental analysis, various spectroscopic methods, single crystal X-ray diffractometry). The complexes show the expected three-legged piano stool structures. Due to steric requirements of the aryl, NHC and posphine ligands, $\mathbf{7}$ and $\mathbf{8}$ may be present as mixtures of several stereoisomers. The isolated compounds, as well as the complexes formed in situ from $\left[\left\{\mathrm{RuCl}_{2}\left(\eta^{6}-p \text {-cymene }\right)\right\}_{2}\right]$ (1) and bmim.HCl, or $\left[\mathrm{RuCl}_{2}(\mathrm{bmim})\left(\eta^{6}-p\right.\right.$-cymene $\left.)\right](\mathbf{3})$ and $\mathrm{PPh}_{3}$ showed good catalytic activity in racemization of optically active secondary alcohols. The highest catalytic turnover frequency, TOF=9.3 $\mathrm{h}^{-1}$ was determined in racemization of $(S)-1$-phenylethanol with the $\left[\mathrm{RuCl}_{2}(\mathrm{bmim})\left(\eta^{6}-p\right.\right.$-cymene $\left.)\right]$ (3) $+\mathrm{PPh}_{3}$ catalyst in toluene at $95^{\circ} \mathrm{C}$. Formation of acetophenone byproduct could be suppressed by using a toluene:isopropanol=5:1 mixture as solvent in which racemization of (S)-1-phenylethanol resulted in 3.4\% ee and 3.5\% yield of acetophenone. DFT calculations on the possible reaction mechanism suggested the key role of an $\left[\mathrm{Ru}(\mathrm{NHC})\left(\eta^{6} \text {-arene }\right)\right]^{2+}$ species in the catalytic cycle, with coordination of hydrogen on the chiral carbon atom of the alcohol to the $\mathrm{Ru}(\mathrm{II})$ center as the rate determining step.

\section{Supporting Information}

For the new compounds 4-8: Synthetic procedures, ${ }^{1} \mathrm{H},{ }^{13} \mathrm{C},{ }^{31} \mathrm{P}$ NMR and ESI MS spectra, ORTEP diagrams with selected bond lengths and angles, capped sticks structures, discussion 
of solid state structures, DFT calculations for possible isomers of 7, and Cartesian coordinates of the DFT optimized structures.

\section{Acknowledgement}

This work was supportedby the EU and co-financed by the European Regional Development Fund under the project GINOP-2.3.2-15-2016-00008. Financial support by the Hungarian National Research Fund (OTKA-NKFIH K101372 to F.J. and NK105691 to É.K.) is gratefully acknowledged. The research was partially supported by the European Union and the European Social Fund through project Supercomputer, the national virtual lab (TAMOP4.2.2.C-11/1/KONV-2012-0010) (M.P.). The authors thank Dr. Attila Kiss for the elemental analyses and Dr. Tibor Nagy for the ESI-MS measurements. N.M. is grateful to the Gedeon Richter Centenary Fund for financial support.

\section{References}

[1] K. Öfele, J. Organomet. Chem. 12 (1968) 42-43.

[2] H.-W. Wanzlik, H.-J: Schönherr, Angew. Chem. 80 (1968) 154.

[3] S. Díez-González, N. Marion, S.P. Nolan, Chem. Rev. 109 (2009) 3612-3676.

[4] S. Díez-González (Ed.), N-Heterocyclic Carbenes. From Laboratory Curiosities to Efficient Synthetic Tools. Royal Society of Chemistry, Cambridge, U.K., 2011.

[5] C.S.J. Cazin (Ed.), N-Heterocyclic Carbenes in Transition Metal Catalysis and Organocatalysis. Catalysis by Metal Complexes, Vol. 32, Springer, Dordrecht, The Netherlands, 2011.

[6] S.P Nolan (Ed.), N-Heterocyclic Carbenes: Effective Tools for Organometallic Synthesis. Wiley-VCH, Weinheim, Germany, 2014. 
[7] M. Bortenschlager, J. Schütz, D. von Preysing, O. Nuyken, W.A. Herrmann, R. Weberskirch, J. Organomet. Chem. 690 (2005) 6233-6237.

[8] N.B. Jokić, M. Zhang-Presse, S.L.M. Goh, C.S. Straubinger, B. Bechlars, W.A. Herrmann, F.E. Kühn, J. Organomet. Chem. 696 (2011) 3900-3905.

[9] H. Syska, W.A. Herrmann, F.E. Kühn, J. Organomet. Chem. 703 (2012) 56-62.

[10] D. Jantke, M. Cokoja, A. Pöthig, W.A. Herrmann, F.E. Kühn, Organometallics 32 (2013) $741-744$.

[11] W.A. Herrmann, M. Elison, J. Fischer, C. Köcher, G.R.J. Artus, Angew. Chem. Int. Ed. Engl. 34 (1995) 2371-2374.

[12] J. Bosson and S.P. Nolan, J. Org. Chem. 75 (2010) 2039-2043.

[13] J. Bosson, A. Poater, L. Cavallo, S.P. Nolan, J. Am. Chem. Soc. 132 (2010) 1314613149.

[14] P. Nun, G.C. Fortman, A.M.Z. Slawin, S.P. Nolan, Organometallics 30 (2011) 63476350.

[15] J.A. Fernández-Salas, S. Manzini, S.P. Nolan, Chem. Eur. J. 20 (2014) 13132-13135.

[16] T.D. Palluccio, X. Cai, S. Majumdar, L.F. Serafim, N.C. Tomson, K. Wieghardt, C.S.J. Cazin, S.P. Nolan, E.V. Rybak-Akimova, M.A. Fernández-González, M. Temprado, B. Captain, C.D. Hoff, J. Am. Chem. Soc. (2017) doi: 10.1021/jacs.7b09905.

[17] D. Janssen-Müller, C. Schlepphorst, F. Glorius, Chem. Soc. Rev. 46 (2017) 4845-4854.

[18] W. Li, M.P. Wiesenfeldt, F. Glorius, J. Am. Chem. Soc. 139 (2017) 2585-2588.

[19] S. Ibáñez, M. Poyatos, L.N. Dawe, D. Gusev, E. Perís, Organometallics 35 (2016) 27472768.

[20] E. Perís, Chem. Rev. (2017) doi:10.1021/acs.chemrev.6b00695.

[21] P. Csabai, F. Joó, Organometallics 23 (2004) 5640-5643. 
[22] J. DePasquale, N.J. White, E.J. Ennis, M. Zeller, J.P. Foley, E.T. Papish, Polyhedron 58 (2013) 162-170.

[23] M. Fekete, F. Joó, Catal. Commun. 7 (2006) 783-786.

[24] E. Mas-Marzá, M.J. Page, M.K. Whittlesey, in: C.S.J. Cazin (Ed.), Catalysis by Metal Complexes, Springer, Dordrecht, The Netherlands, 2011, Vol. 32, pp. 207-216.

[25] N. Marozsán, H. Horváth, A. Erdei, F. Joó, J. Mol. Catal. A: Chem. 425 (2016) 103-109. [26] W. Gil, A.M. Trzeciak, Coord. Chem. Rev. 255 (2011) 473-483.

[27] M.K. Samantaray, M.M. Shaikh, P. Ghosh, J. Organomet. Chem. 694 (2009) 3477-3486.

[28] C. Fleckenstein, S. Roy, S. Leuthäußer, H. Plenio, Chem Commun. (2007) 2870-2872.

[29] A. Azua, S. Sanz, E. Perís, Chem. Eur. J. 17 (2011) 3963-3967.

[30] Cs.E. Czégéni, G. Papp, Á. Kathó, F. Joó, J. Mol. Catal. A: Chem. 340 (2011) 1-8.

[31] H.D. Velazquez, F. Verpoort, Chem. Soc. Rev. 41 (2012) 7032-7060.

[32] L. A. Schaper, S. J. Hock, W.A. Herrmann, F.E. Kühn, Angew. Chem. Int. Ed. 52 (2013) 270-289.

[33] E. Levin, E. Ivry, C.E. Diesendruck, N.G. Lemcoff, Chem. Rev. 115 (2015) 4607-4692.

[34] A. Almássy, Cs.E. Nagy, A. C. Bényei, F. Joó, Organometallics 29 (2010) 2484-2490.

[35] H. Horváth, Á. Kathó, A. Udvardy, G. Papp, D. Szikszai, F. Joó, Organometallics 33 (2014) 6330-6340.

[36] H. Horváth, G. Papp, R. Szabolcsi, Á. Kathó, F. Joó, ChemSusChem 8 (2015) 30363038.

[37] H.M.J. Wang, I.J.B. Lin, Organometallics 17 (1998) 972-975.

[38] H. Pellissier, Tetrahedron 64 (2008) 1563-1601.

[39] O. Pámies, J.-E. Bäckvall, Trends Biotechnol. 22 (2004) 130-135.

[40] M.-J. Kim, Y. Ahn, J. Park, Curr. Op. Biotechnol. 13 (2002) 578-587.

[41] Y. Ahn, S.-B. Ko, M.-J. Kim, J. Park, Coord. Chem. Rev. 252 (2008) 647-658. 
[42] Y. Blum, D. Czarkie, Y. Rahamim, Y. Shvo, Organometallics 4 (1985) 1459-1461.

[43] R. Karvembu, R. Prabhakaran, K. Natarajan, Coord. Chem. Rev. 249 (2005) 911-918.

[44] J. H. Koh, H. M. Jeong, J. Park, Tetrahedron Lett. 39 (1998) 5545-5548.

[45] D. Lee, E.A. Huh, M.-J. Kim, H.M. Jung, J.H. Koh, J. Park, Org. Lett. 2 (2000) 23772379.

[46] G. Csjernyik, K. Bogár, J.-E. Bäckvall, Tetrahedron Lett. 45 (2004) 6799-6802.

[47] M. Ito, A. Osaku, S. Kitahara, M. Hirakawa, T. Ikariya, Tetrahedron Lett. 44 (2003) $7521-7523$

[48] M. J. Hateley, D. A. Schichl, H.-J. Kreuzfeld, M. Beller, Tetrahedron Lett. 41 (2000) $3821-3824$

[49] E.J. Ebbers, G.J.A. Ariaans, J.P.M. Houbiers, A. Bruggink, B. Zwanenburg, Tetrahedron 53 (1997) 9417-9476.

[50] J. Nyhlén, T. Privalov, J.-E. Bäckvall, Chem. Eur. J. 15 (2009) 5220-5229.

[51] M.J. Stirling, J.M. Mwansa, G. Sweeney, A.J. Blacker, M.I. Page, Org. Biomol. Chem. 14 (2016) 7092-7098.

[52] A. Dijksman, J.M. Elzinga, Y.-X. Li, I.W.C.E. Arends, R.A. Sheldon, Tetrahedron Asym. 13 (2002) 879-884.

[53] T.H. Riermeier, P. Gross, A. Monsees, M. Hoff, H. Trauthwein, Tetrahedron Lett. 42 (2005) 3403-3406.

[54] M. Merabet-Khelassi, N. Vriamont, L. Aribi-Zouioueche, O. Riant, Tetrahedron Asym. 22 (2011) 1790-1796.

[55] O. Pámies, J.-E. Bäckvall, Chem. Eur. J. 7 (2001) 5052-5058.

[56] B. Martín-Matute, J.B. Åberg, M. Edin, J.-E. Bäckvall, Chem. Eur. J. 13 (2007) 60636072. 
[57] T. Jerphagnon, A.J.A. Gayet, F. Berthiol, V. Ritleng, N. Mršic, A. Meetsma, M. Pfeffer, A.J. Minnaard, B.L. Feringa, J.G. de Vries, Chem. Eur. J. 15 (2009) 12780-12790.

[58] H. Cao, L.-H. Cai, C.-X. Wang, X.-H. Zhu, Z.-M. Li, X.-F. Hou, J. Organomet. Chem. 775 (2015) 60-66.

[59] M.A. Bennett, A.K. Smith, J. Chem. Soc., Dalton Trans. (1974) 233-241.

[60] R.A. Zelonka, M.C. Baird, Can. J. Chem. 50 (1972) 3063-3072.

[61] C.S. Allardyce, P.J. Dyson, D.J. Ellis, S.L. Heath, Chem.Commun. (2001) 1396-1397.

[62] V. Cadierno, J. Francos, J. Gimeno, Chem. Eur. J. 14 (2008) 6601-6605.

[63] D.J. Daigle, Inorg. Synth. 32 (1998) 40-45.

[64] The Cambridge Structural Database (Version 5.38, Update Feb, 2017), C. R. Groom, I. J. Bruno, M.P. Lightfoot, S.C. Ward, Acta Cryst. B72 (2016) 171-179.

[65] X. Xie, H.V. Huynh, ACS Catal. 5 (2015) 4143-4151.

[66] A. Bittermann, D. Baskakov, W.A. Herrmann, Organometallics 28 (2009) 5107-5111.

[67] R. Sundberg, R.F. Bryan, I.F. Taylor, Jr., H. Taube, J. Am. Chem. Soc. 96 (1974) 381 392.

[68] R.L. Chowdhoury, J.-E. Bäckvall, J. Chem. Soc., Chem. Commun. (1991) 1063-1064.

[69] D. Wang, D. Astruc, Chem. Rev. 115 (2015) 6621-6686. 